\title{
HACIA UNA \\ DIDÁCTICA COMPRENSIVO EDIFICADORA
}

\section{TOWARDS A COMPREHENSIVE EDIFYING DIDACTIC}

\author{
Julio César Arboleda \\ Director Red Iberoamericana de Pedagogía \\ Grupo de Investigación Redipe \\ direccion@redipe.org
}

\section{RESUMEN}

A la luz de orientaciones tales como las pedagogías mesoaxiológica, de la alteridad, radical - inclusiva, y en particular la perspectiva comprensivo edificadora (PCE) de la educación y la formación que el autor ha venido proponiendo en la última década, este documento, de carácter crítico y propositivo, expone algunas deudas de la didáctica, atada a la soberbia de la racionalidad y el pensamiento moderno, así como ideas, conceptos y estratagemas para una didáctica otra que tenga al ser humano, la vida y la existencia como piedra angular y sentido que impulsa sus ocupaciones como dominio multisaber en torno a la enseñanza, la formación y los aprendizajes. De la misma manera se hace énfasis en algunos tratamientos críticos y discursivos, todos los cuales superan el carácter técnico, deóntico y ensimismado que pesa en la didáctica y en la educación por encima del
Para citar: Arboleda, J.C. (2020). Hacia una didáctica comprensivo edificadora. En: En A. Medina Rivilla, A. de la Herrán Gascón y M. C. Domínguez Garrido (Coords.), Hacia una didáctica humanista (pp. 389-460). Madrid: REDIPE-UNED

precepto supremo de servir propósitos humanizantes, y que por efecto va más allá de visiones y constructos entregados a las lógicas y tecnicismos de enseñabilidad del saber. Algunas de las reconceptualizaciones, nociones y nuevos conceptos, inherentes a la PCE de la didáctica, la pedagogía y la educación, que tienen lugar a lo largo de la exposición, son, entre otros: didáctica, enseñar educando, enseñanza, comprensión, CE, PCE, calidad educativa, vida, proyectos de vida, humanización de la educación y de la didáctica, evaluación edificadora, alteridad ética, DCE, episteme comprensivo edificadora, lógicas sentientes, pausa didáctica, parto pedagógico formativo, ACE, ECE, desarrollo/evolución humano, comprensión ética, praxis formativa comprensiva, ótrico.

PALABRAS CLAVE: enseñar educando, alteridad, parto pedagógico, didáctica - aprendizaje 
- enseñanza - formación - evaluación - comprensión edificadora, episteme, ótrico.

\section{ABSTRACT}

In light of orientations such as mesoaxiological, alterity, radical - inclusive pedagogies, and in particular the comprehensive edifying perspective (PCE) of education and training that the author has been proposing in the last decade, this document critical and purposeful character, it exposes some debts of the didactics, tied to the arrogance of rationality and modern thought, as well as ideas, concepts and stratagems for another didactics that has the human being, life and existence as a cornerstone and a sense that drives their occupations as a multi-knowledge domain around teaching, training and learning. In the same way, emphasis is made on some critical and discursive treatments, all of which exceed the technical, deontic and self-absorbed character that weighs on didactics and education above the supreme precept of serving humanizing purposes, and which by effect goes further beyond visions and constructs delivered to the logics and technicalities of the teachability of knowledge. Some of the reconceptualizations, notions and new concepts, inherent to the ECP of didactic, pedagogy and education, that take place throughout the exhibition, are, among others: didactic, teaching/educating, teaching understanding, CE, PCE, educational quality, life, life projects, humanization of education and didactics, edifying evaluation, ethical alterity, DCE, comprehensive edifying episteme, sentient logics, didactic pause, formative pedagogical birth, ACE, ECE, development / human evolution , ethical understanding, comprehensive formative praxis, otric.

KEY WORDS: teaching/educating, alterity, pedagogical childbirth, didactic - learning - teaching - training - evaluation - edifying understanding, episteme, otrico.

\section{A MODO DE INICIO: LA DIDÁCTICA Y LA FUNCIÓN DE EDUCAR}

La didáctica es entendida en nuestro documento como universo del saber que aborda de modo teórico, metateórico, práctico y aplicado las situaciones de la enseñanza, la formación y el aprendizaje o praxis de la apropiación y movilidad de conocimientos, saberes, conceptos, valores y actitudes en un entorno escolarizado situado, valga señalar, en un espacio temporal y contextualmente dado. $Y$ referida tanto al campo didáctico (metadisciplina, diálogo interdidáctico) que sigue analógicamente el movimiento de las disciplinas, comunidades y saberes que lo conforman, allí las didácticas o comunidades disciplinarias; como a las didácticas comparativas y profesionales, la metódica, los paradigmas, los modelos, las reconstrucciones (didácticas), y en general "à peu près la totalité des sciences de l'éducation, une large part de la psychologie, de l'anthropologie, de la sociologie"; campo que, de acuerdo con Chevallard (citado por Didier Cariou y otros, 2015) ha de seguir construyéndose, en lo posible, sugerimos, mirando no solo desde el saber y los aprendizajes, sino desde el cristal de la vida, desde la lente del saber para ser (que implica el hacer, más que exclusivamente para hacer); desde las enseñanzas, formaciones y aprendizajes que humanicen a tono con la función de educar, tarea dirigida a formar mejores seres y que pasa por intervenir en la creación de mayor consciencia de mundo común, por lo que es menester su relocalización en el acto educativo y didáctico.

Partiendo de esta idea común a todos los saberes y conocimientos que integran el campo, el complejo didáctico, se podría esperar que los hallazgos y construcciones en los movimientos de éste abonen a los objetos puntuales mono, inter e intradisciplinares de la didáctica, tributando de manera auténtica al proyecto de vida educativo bajo principios y objetivos humanizantes. Para lo cual es necesario que la didáctica vaya 
más allá de los aprendizajes y el saber, y afirme, no soslaye su relación con la función de educar, si se prefiere de enseñar educando para promover aprendizajes formativos, que empoderen a los agentes educativos como mejores seres humanos.

Algunas de las limitaciones de la didáctica que se exponen en las siguientes líneas tienen que ver con un descuido abisal, radical si se prefiere, de fines y preceptos medulares en la educación y la pedagogía. Muchas de estas se avistan en definiciones desnaturalizantes del concepto didáctica, que descansan sobre los aprendizajes y los saberes, es decir cuando se considera que el deber ser de la didáctica son estos por encima de la enseñanza y la formación; fenómeno de intrusión epistémica y reduccionismo eficientista, liderado entre otros por las lógicas egocéntricas del rendimiento que nacen en el orbe del mercado, por el cual se traslapa y enturbia la personalidad de la didáctica hasta el grado de que la voz de esta se torna a veces la voz del dominio de disciplinas como la psicología -- en particular la psicología del apredizaje y de la cognición, junto con perspectivas y enfoques educativos ligados a esta --, que la extravían de su cause original de ofrecer enseñanzas y formaciones para ser, para una comprensión consciente, si se prefiere para un hacer que dignifique, enseñanzas que eduquen, y no solo enseñanzas para saber y aprender, es el caso del enfoque por competencias, que aboca a la didáctica al saber hacer, o el constructivismo, limitado a brindar los mejores escenarios para apropiar y construir conocimiento; tanto como aquellas centradas en la neurociencia, las inteligencias, la razón o el pensamiento cognitivo, conceptual e inclusive crítico, que finalmente desembocan en el saber, el saber hacer ${ }^{1}$.

$1 \quad$ Pespectivas y disciplinas estas que desde la ética y la antropología en las que se sustenta la función de educar, podrían encontrar un sentido menos instrumental, más regulador de su aplicación y tratamiento, para obrar con sentido ótrico, es decir por el bien personal, particular y común. Al respecto, revestiría gran importancia en las ciencias sociales los aportes de la disciplina de la ética de las neurociencias para morigerar la conducta investigativa científica obsesiva
Las reflexiones pedagógico - didácticas que se esbozan aquí, sintetizadas en la expresiones "enseñar educando" y "saber ser otro", desde la cual salvamos nuestra visión didáctica del anquilosamiento en el saber y los aprendizajes, no obstante retoman elementos del pensamiento didáctico occidental (alemán, anglosajón, francés), van más allá del mismo, de su encapsulamiento en la triada didáctica maestro, alumno y saberes ${ }^{2}$ - y sobre todo por sus descuidos o timidez respecto a la función de educar -- corazón de todos los saberes asociados a la educación -, a la "sensibilización" de las transposiciones didácticas ${ }^{3}$, a la humanización de todas las prácticas y saberes educativos (incluidas las didácticas) de modo que coincidan con el ser o intencionalidad profunda de la educación a favor de la existencia, de la vida (una y otra como campos de sentido), del hombre, y la interdependencia entre estos.

La didáctica, enmarcada en dicho pensamiento, se despersonaliza, evade, como saber pedagógico-educativo, su función inalienable de humanizar, de formar mejores personas desde las enseñanzas y situaciones del aprendizaje, según se reflexiona en diversos recodos del documento. Este último dirigido, no a discutir expresamente el pensamiento pedagógico y didáctico occidental, sino a proponer y argumentar una perspectiva para la didáctica que propugne por la acción de enseñar educando, en la cual dicho pensamiento presenta severos pasivos.

La actual didáctica suele descuidar que la Pedagogía, tomando como base los rasgos que determinan y cualifican el significado de educación,

que aborda el cerebro, a fin de interponer reflexiones y acciones frente a los usos malsanos de las funciones cerebrales; tanto como la neuroética, el estudio del impacto neurocientífico en la conducta moral.

$2 \quad$ Que deja de lado componentes de orden temporal, espacial, intencional y demás; su circunscripción a uno $u$ otro elemento del triángulo.

3 De modo que la intervención en los aprendizajes no solo encuentre el tono apropiado para la subjetivación o apropiación del saber por el estudiante, sino que haga parte de un acogimiento generativo del estudiante como otro, como educando en situación de humanización, de objetivación humanizante del saber para ser mejor gente. 
diferencia, de acuerdo con Touriñan $(2017)^{4}$, entre conocer, enseñar y educar, genera conocimiento de la educación y establece principios de educación y de intervención pedagógica para el control de la acción en cada ámbito de educación construido ${ }^{5}$.

En esta dirección, el asunto de la didáctica no puede reducirse a los aportes que, en materia de reflexión, investigación, organización, intervención e implementación, realice en los procesos de conocer, enseñar y aprender; le cabe saldar el pasivo que generalmente presenta este campo plural del conocimiento frente a la función de educar para saber ser mejor persona. Detengámonos un poco en este punto.

Educar es el acto por el cual se generan oportunidades y potenciales para la formación de sujetos que usen sus comprensiones y potenciales a favor de su crecimiento como persona y de la evolución de la vida humana y planetaria. No es posible educar bajo criterios de progreso humana y existencialmente involutivos, como los que impone la modernidad capitalista. Se educa para un desarrollo social humanizado, que

$4 \quad$ Creador de la pedagogía mesoaxiológica, alternativa emergente dirigida a la mejora de la capacidad de análisis, interpretación y comprensión de la educación, así como a la resolución de problemas desde el concepto de ámbito de educación, haciendo posible el despliegue de diseños y de programas de acción educativa concreta, controlada y programada, de manera que la función pedagógica adquiera sentido profesional de competencia técnica con fundamento en la mentalidad pedagógica específica y en la mirada pedagógica especializada en cada intervención (Arboleda, 2020, p. 35).

$5 \quad$ Al respecto, Touriñan (2020b) pone de presente que "conocer, enseñar y educar no significan lo mismo. Para enseñar, además de conocer, hemos de conseguir que el educando haga cosas para que llegue a conocer y actuar. Para educar hemos de dar un paso más allá, porque hay enseñanzas que no educan: tenemos que valorar cada medio que utilizamos como educativo y ajustarlo a los rasgos inherentes al significado de educar. El objetivo de conocer es llegar a saber, el objetivo de enseñar es hacer saber y actuar a otro. El objetivo de educar es conseguir que el educando se capacite para decidir y realizar sus proyectos, y se convierta en agente actor y autor de esos proyectos".

De lo que se trata en cada ámbito de educación configurado desde un área cultural (las disciplinas del conocímiento, ahi la filosofía, las matemáticas, la biología) es disponer de la experiencia axiológica de cada área cultural como instrumento de la construcción de uno mismo y de formación bajo la forma de aprendizaje situado en un tiempo y espacio físico-personal-sociohistórico- cultural concretos. aporte sustantivamente a la evolución de la vida humana y planetaria (Arboleda, 2020c). Es este un acto sin lugar a dudas ético -- de respuesta compasiva al sujeto educable y a los seres que nos recuerdan, mediante un eterno aullido lúgubre, que somos parte de un tejido común, demandándonos sentido común --, y de encuentro único e irrepetible con el otro y con lo otro como a priori de la condición humana.

Es deseable, desde una perspectiva comprensivo edificadora (PCE), que los acercamientos de tipo teórico, técnico o práxico que se constituyen en objetivo de abordaje en la enseñanza, no avancen desvinculados de la ética y al margen de la relación interconectada entre estos procesos ${ }^{6}$. Para ello es necesario crear en el marco de la enseñanza, la formación y la didáctica contrafuerzas que enfrenten el agregamiento cuando no el crecimiento de perspectivas y enfoques de saber que, bajo el influjo de la episteme moderna o egoepisteme, como se explica luego, subordinada a su vez a intereses antropocéntricos e individualistas, proyectan sus ideas y dispositivos desde el prisma discursivo del mundo del mercado (que en virtud al absolutismo del ego hace de las relaciones sociales y de existencia un comercio, un consumo de mundos de vida), los cuales terminan relegando el arjé de la educación, negándose a abordar de manera interrelacionada los procesos mencionados, y se abandonan por el contrario al imperio del

$6 \quad$ Aunque aquí se demarca la importancia de incluir la función de educar en los actos de conocer, aprender y enseñar, es decir que quienes conozcan, enseñen y aprendan lo hagan con sensibilidad humana, edificante $u$ ótrica si se prefiere, no se pretende imponer que la enseñanza solo es enseñanza si educa (aunque para Comenio, siguiendo a Runge P., A. Klaus (2013), "no hay enseñanza que no eduque en algo"); no se desconoce aquí que conocer, enseñar, aprender y educar son independientes, valga señalar que el propósito de educar no hace parte de las propiedades características de los conceptos enseñar, aprender y conocer, y que es válido en consecuencia enseñar sin el objetivo de educar, y que no necesariamente las enseñanzas que no educan (las de instrucción, las de información de datos y las enseñanzas de rasgos culturales) dejan de ser técnicamente bien hechas. El asunto que nos motiva aquí es la nimia visibilización de la tarea de educar en los procesos de intervención y en los acercamientos pedagógicos y didácticos. 
"ajuste y del encaje" al que obligan los sistemas económicos y políticos hegemónicos.

Hay una brecha planetaria entre la narrativa de las políticas e intenciones institucionales, estatales y globales, y la realidad hirviente en la que se calcinan la existencia y la vida. $Y$ esa deuda orbital del hombre con lo humano y la existencia se visibiliza en la educación vestida de intenciones y políticas que no alcanzan a cubrir los actos educativo y pedagógico ${ }^{7}$. Consecuentemente, propendemos desde aquí por una pedagogía y didáctica que permitan generar una consciencia crítica y activa sobre procesos, fenómenos, perspectivas y supuestos que atan la educación alrededor de la impositividad, del deber ser, de prescripciones eficientistas para saber hacer, que abiertamente idealizan, despersonalizan al docente y su práctica; nos interesa aquí proponer y reivindicar orientaciones pedagógicas y didácticas fundamentadas desde el principio de humanidad al que exhorta la buena pedagogía, que no ignoren el saber ser como sentido palmario del quehacer educativo y pedagógico, como principio para humanizar al

$7 \quad$ Extrapolando a Badiou (2016) en tanto sentencia que lo real siempre está enmascarado, que la democracia es el semblante (la máscara real) en la cual se encubre el real capitalismo imperialista; la educación, como derecho humano, constituiría igualmente la funda que cubre la episteme y la razón moderna colonizante. En el marco de las contradicciones que la consciencia comprensiva encuentra tanto en la democracia como en la educación, se dejan apropiar los órdenes que usan estas para regir su permanencia. El ejercicio crítico-comprensivo nos permite apreciar la realidad de la funda y la del enfundado. En la realidad concreta de la cubierta educativa se deja ver lo real de la razón enmascarada: se trata de una educación alienada, desorientada de sus principios originales y más sentidos, que encontraría en la función de educar el espacio para aportar a los procesos de humanización que alientan los postulados de una razón edificante; una educación al servicio de la razón despótica que alcanza a los saberes educativos, ahí la pedagogía y por supuesto la didáctica, que les despoja, excluye de su misión auténtica coaccionándolos a fungir de dispositivos técnicos para labrar los estilos y formas de vida que oxigenan el ordenamiento tecnocientífico y financiero que dispone del planeta y de la vida humana. Ello pone en evidencia la necesidad de rebobinar el esquema de percepción que domina y reproduce la educación, para redescubrir y enfrentar el fondo real de la canción que nos hacen entonar la educación, la pedagogía y la didáctica. Ese es el sentido de la perspectiva Compresión edificadora (PCE) al procurar elementos para una mirada actuante que nos ponga en condición de obrar en las realidades encubiertas para construir realidades $y$ mundos más humanos. docente, a los sujetos de la relación educativa y la existencia, según se esclarece más adelante.

La didáctica participa en la valoración que hace la pedagogía de las áreas culturales (historia, biología, etcétera), para dotar de significado las prácticas educativas y configurarse como ámbitos de educación ${ }^{8}$, es decir como constructos que corren paralelas con los fines y connotaciones de la educación, y por inferencia con la función de educar (desde y con los ámbitos), pues la actividad educativa es "educativa", de acuerdo con Touriñán (2019), porque tiene la finalidad de educar. Exactamente aquí interesa su relación con la función de educar, en tanto foco de la relación educativa, de la cual, a nuestro juicio, no debiera sustraerse aquella.

\section{El documento indaga en torno deudas didácticas} en esta materia. Asunto que se complejiza si tenemos en cuenta que cada disciplina y ámbito cultural de conocimiento tiene sus propias dinámicas para abordar pedagógica, epistemológica y didácticamente los procesos de enseñanza, formación y aprendizaje ${ }^{9}$. Primero, expone algunos de sus descuidos con relación a la función de educar y en general con la necesidad de establecer nuevas formas relacionales de ser, de estar, de hacer y conocer.

\section{Del mismo modo se examinan las contribuciones} de enfoques no lineales que reconocen la didáctica como un campo que no ha de preterir

\footnotetext{
8 De acuerdo con Touriñán (Vol 6/11, 2017), Ámbito de educación" es un concepto que tiene significación propia desde el conocimiento de la educación y está vinculado a los rasgos que determinan y cualifican el significado de la educación, a los procesos de intervención, a las dimensiones generales de intervención, y a las áreas de experiencia y formas de expresión que mejor se ajustan a cada actuación. $9 \quad$ La historia de las disciplinas escolares como fenómenos sociales ofrece pistas sobre los aspectos que intervinen en la mecánica de su construcción, transformación y modificabilidad. Los intereses económicos no solamente inciden en las variaciones de las disciplnas y curriculos; también los debates entre los mismos agentes disciplinares, y en otras ocasiones, por las presiones externas de tipo político y cultural. Al decir de Gonzáles (2014), "son el resultado de una intensa relación entre los miembros del campo y las presiones que se pueden ejercer desde el ámbito político $u$ otras esferas sociales".
} 
la contingencia, inestabilidad, incertidumbre y provisionalidad de los saberes y los conocimientos, de los procesos cognoscitivos, de la influencia educativa y de las distintividades territoriales, culturales y económicas, así como de los propios sujetos de la relación educativa; didácticas que realmente coadyuvan en la consolidación de aprendizajes comprensivos que animen la formación de seres con capacidad de politicidad en su accionar, con gobierno propio y sensibles con la condición del hombre y la vida; en especial los méritos de la comprensión edificadora, $\mathrm{CE}^{10}$; y en el interregno, dispensa conceptos que podrían servir en prácticas específicas de la enseñanza en cada campo del saber y del conocimiento. Finalmente expone, por una parte, ciertas ideas sobre la necesidad de rumbear hacia una didáctica comprensivo edificadora (DCE), o si se quiere, hacia una PCE más cercana aún a la función de educar, que sirva a los fines de humanización de la didáctica ${ }^{11}$, las disciplinas $10 \quad$ Por lo pronto digamos que la comprensión edificadora (CE) representa un constructo que aboga por una formación para la consciencia, que permita a los agentes educativos ganar comprensiones, usando estas con sentido humano y de mundo común. En este punto la didáctica no es impermeable frente a las presiones externas de tipo ideológico, político y financiero dirigidas a impactar la ciencia, la tecnología, la cultura y la sociedad. Justamente la PCE está en la línea de los acercamientos didácticos de carácter teórico y/o metodológico que visibilizan tal enajenación reivindicando los objetivos humanizantes de la educación y por efecto de la didáctica, aunque también es consciente que muchos de estos no han alcanzado a ir más allá de sus prédicas, pues algunos de sus actores, sean pedagogos, didactas $u$ otros agentes educativos, terminan siendo cómplices, aún por omisión, al mirar sin ver la problemática de la contaminación que afecta a la educación y a la didáctica como ciencia, contraviniendo los principios, reglas y pautas de comportamiento que nutren a estas como instituciones sociales. La didáctica es plural más no homogénea, pues dentro de ella hay tanto reflexiones y prácticas soberanas como otras que legitiman propuestas distanciadoras que vienen del capital, por ejemplo el enfoque por competencias que los sistemas educativos proclives al orden del mercado depredador están obligados a servir.

11

La humanización es, interpolando a Levinas (1977), hospitalidad, fraternidad. Ya hemos presentado en otros documentos una percepción de humanización que se distancia radicalmente de las nociones que sobre lo humano ha impuesto el Estado moderno a través de sus instituciones. La humanización es entendida, por nuestra parte, como la actitud favorable a establecer relaciones de existencia en la sociedad ecosistémica reguladas por los principios de responsabilidad y respeto por la vida, la dignidad humana, el otro y lo otro. Sobre todo en un contexto de avance y las prácticas escolares, por los que aquí se aboga; y por otra, sugiere algunas estrategias que podrían ser útiles a las motivaciones pragmáticas de toda didáctica inherentes a una intervención adecuada y efectiva, tanto como al empleo del aparato analítico, sea de resorte histórico, filosófico, cognoscitivo, social y cultural, entre otros, en virtud del cual estas capturan los fenómenos de la enseñanza y el aprendizaje en un dominio dado del conocimiento, es el caso de la pausa didáctica, el aprendizaje comprensivo edificador (ACE) -- que incluye el Taller comprensivo edificador y las relatorías edificadoras, la metodología de Aprendizaje por problemas edificadores (APE)-, los pensamientos múltiples y la enseñanza por proyectos de vida.

Con todo, nuestra propuesta no persigue constituir "garantía de viabilidad para el funcionamiento de cualquier práctica educativa concreta"12, pero podría tener un valor preciado (agregamiento) tecnocientífico -- inspirado al mismo tiempo por ideales nobles como por egocentrismos económicos e ideológicos --, que ha logrado alterar genéticamente la vida y la existencia hasta el punto de crear y modificar nuevas formas de vivir y de existir, afectando las fronteras y límites históricamente consensuados en materia corporal, existencial y epistémica, impactando tanto en la definición de los conceptos ser humano, vida y existencia, los cuales, dada esta inminente interconexión de carácter molecular, han de introyectar ahora propiedades inherentes al lenguaje genético-digital, como en las epistemes del saber y de la vida, según se torna al tema posteriormente.

En esta orientación la eticidad o humanización de los saberes, en nuestro caso ligados a la educación, es necesaria para hacer contrapeso a los acercamientos disciplinares y de saber cuyas indagaciones se adecúan a las expectativas del poder global, mejor al proyecto específico contra el ser humano que podríamos nombrar epi(stemo)genético, a través del cual la alianza episteme moderna - poder financiero y tecnocientífico pone a su servicio el conocimiento, incluido el de la neurociencia que aborda el impacto genético de la pobreza y la desigualdad en materia psíquica y fisiológica (Lipina, Sebastián J., Evers, Kathinka, 2017). Estudio que nos permite advertir el antropomorfismo peyorativo que esta duo-deidad, si se me permite, instala sistemáticamente en la vida de los seres humanos, haciendo su existencia cada vez más precaria, que se traduce siempre en un ser siendo menos, en corte inexorable de humanidad en cada ser, más dramático en la población pobre que crece al ritmo de la tecnociencia que alimenta el espítitu globalizante.

$12 \quad$ Al respecto Arboleda, L.C.- Castrillón, G.(2007), retomando a Johsua y Dupin (1993), advierten que "es poco probable que un conocimiento particular pueda ser (re) construido a partir de un conocimiento general de los fenómenos de enseñanza y las reglas del aprendizaje", como es el caso de alguna perspectiva pedagógica o didáctica general. 
en los procesos de reformulación teórica y metodologica que requieren la pedagogía y las ciencias de la educación, ahí la didáctica, para presionar la descolonizacion epistémica ${ }^{13}$. En dicha tarea es fundamental que el profesional docente aprenda a refinar el saber disciplinar en virtud al conocimiento de la educación, siendo preciso que lo ajuste al significado de esta como condición para enseñar educando, atendiendo siempre a principios sentidos de educación e intervención.

\section{DESORIENTACIÓN DE LA DIDÁC}

\section{TICA}

En este aparte se precisan algunos pendientes de la didáctica respecto a radicales humanos, ambientales, sociales, culturales/ espirituales e históricos que esta conlleva en sus construcciones y prescripciones ${ }^{14}$, atravesada por una lógica (didáctica) que sigue soslayando, además de la función de educar, las singularidades individuales, sociales y culturales, y según la cual, para decirlo con Gaete V. M. (2015), "'los sujetos deben aprender ciertos contenidos, habilidades, destrezas, competencias, seleccionados para ellos como válidos, ideario sostenido por ciertas lógicas estandarizadas e intereses socioeconómicos y políticos que pretenden configurar un cierto tipo de sujeto y subjetividades proclives al statu quo".

No obstante los saberes concernientes a la

13 La colonización epistémica hace referencia aquí, como se ahondará, a la imposición de la razón y el saber modernos en las prácticas educativas situadas tempoespacialmente, que contaminan la pedagogía y los saberes educativos hasta el grado que les extravía de la función educadora por entregarse al estudio de las formación de sujetos que reproduzcan las lógicas (económicas, financieras, tecnocientíficas) que imperan en el mundo en que viven. 14 Valga aclarar que nuestra crítica no hace parte de las posturas que buscan homogenizar o reducir la didáctica y la ciencia en general. Apunta especificamente a algunos de sus saberes, prácticas y egos que por desconocimiento, intereses creados $u$ otras razones terminan maculando la institución científica al contravenir sus límites éticos $u$ objetivos humanizantes. La heterogeneidad tiene su base no solo en la pluralidad de saberes científicos y dentro de cada uno de estos, sino además en los intereses y propósitos que circulan en los mismos, los propios del investigador, de la organización que representan, de la entidad estatal o privada que financia sus indagaciones, entre otros. educación (ahí la didáctica y sus microsaberes: tipos, tendencias, disciplinas, perspectivas, paradigmas, modelos, métodos, otros) tienen, como conceptos, propiedades únicas que cooperan al establecimiento de sus propios límites, se hallan también, como es de esperarse, arropados por rasgos comunes que los empujan a contribuir de manera abierta en la tarea humanizante, por lo que la didáctica, la pedagogía y la enseñanza no escapan al deber de actuar en la misma dirección. Sin embargo, la didáctica moderna, en particular, parece ignorarlo ${ }^{15}$. Se trata ésta de una didáctica en cierto grado ensimismada, eclipsada como aquellos en sus rasgos diferenciales que les lleva a obrar como partículas limitadas y aisladas, mas tímida y distante aún de sus motivaciones comunes; empeñada en el éxito, mejor, en la rentabilidad de las enseñanzas y los aprendizajes que requiere la estructura desigual o 'modelo civilizatorio' de la modernización globalizada que regla nuestra existencia, con una política del desarrollo que impone los criterios económicos a cualquier empresa sutil con el cuidado del ser humano, el equilibrio y conservación de los ecosistemas, la dignidad o la justicia ecosocial; divorciada por lo tanto del tipo de ser que demanda el cosmos de la vida, un mundo común más humano, basado en un orden civilizatorio con mayores garantías para la educación, la igualdad, la paz, la salud, la alimentación, el trabajo, la equidad, la diversidad biológica y cultural, y las condiciones de existencia digna de los seres vivos y no vivos.

Es ésta una didáctica acendrada en una (ego) episteme como la moderna que no riñe abiertamente con los intereses de poder (en sus diversas formas y niveles) dominantes en las sociedades, para los cuales la enseñanza y los

15 Dicha tarea no aparece ni en la didáctica ni en las prácticas de enseñanza de las cuales bebe aquella, en el cara a cara entre educando y educador que debiera producir la química que humanizaría o reafirmaría el ser de unas y otras: "C'est la profession enseignante, à travers le face à face quotidien avec les élèves, qui est productrice de la didactique" (Jean- Luc Dorier, Francia Leutenegger \& Bernard Schneuwly, 2013). 
aprendizajes deben servir los propósitos de reproducción del orden socio-económico-político bajo el cual se logran perpetuar sus finalidades, un régimen con una noción mísera de la condición humana, que no representa la infraestructura de la vida, la salvaguardia de los derechos fundamentales, ahí la salud, la educación, un medio ambiente sano, una tierra habitable.

La episteme moderna puede entenderse como el marco de saber en el que se inscriben las sociedades e individuos en un momento histórico, que establece las pautas de lo que somos, en el que se producen estilos de vida, de cultura, de creencia, de formación o educación, de relación con nosotros mismos, con el entorno, con la ciencia; es una condición o modo que soporta el pensamiento y la forma de relacionarse con la vida, con el mundo y el conocimiento, de asumir este desde su producción y apropiación cognitiva y social, desde su creación, transferencia y uso en las diferentes sociedades que reivindican al sujeto concreto, su libertad y su manera de ser; constructo desde el cual se define la posibilidad de confrontación, aprobación o negación de los individuos y realidades que nutren la existencia. La modernidad, entendida como modo de pensar y de hacer a través del desarrollo de las ciencias positivistas ${ }^{16}$, es solo condescendiente con aquello que logre sujetar, alinearse en las relaciones y formas de ver, saber y actuar que esta promueve; es un asunto de radical interés para los ideales de progreso a través del desarrollo económico, tecnológico y científico.

La episteme moderna se solaza con la razón (léase también, la comprensión) eurocéntrica excluyente del otro y de lo otro que riña con esta lógica, que está al servicio de la barbarie capitalista, acompañando los fines de desarrollo económico y financiero; representa el sab-

\footnotetext{
$16 \quad$ Las cuales, al decir de De Sousa (1995), cumplieron su función de hacer explicativo modelos de la realidad que funcionaban en la medida que esos modelos reproducían aquellas instancias de la realidad susceptible de control, cálculo, medida y cantidad, como si fuera un objeto concreto en sí mismo.
}

er poder que también agrega a la pedagogía y la didáctica, el desarrollo del conocimiento, del saber, de la ciencia, la cultura y la producción. Con la modernidad epistémico político económica se acumulan periodos constantes de crisis que no dejan de ser "enunciativos", es decir periodos críticos en los que pesan los paradigmas discursivos de la modernidad, la razón-saber-poder dominante, individualista, desigual, antropocéntrica, patriarcal, colonialista, deshumanizante. Una crisis del deterioro de los mundos planetario y humano, que esperan el cumplimiento de sus funciones originales por parte de las organizaciones sociales, de instituciones como la educación y de los saberes más sensibilizados ligados a esta, ahí la pedagogía y la didáctica. Sin esta presión de razonalibilidad, de acciones concretas social, humanamente confiables se eternizan las esperanzas.

Aprisionada en estas redes la didáctica moderna no ha de poder avanzar sobre los postulados edificadores que entraña la función de educar sino sobre las ruedas de la eficiencia y la técnica. No podrá ser una didáctica sentida, edificadora, sino disfuncional, inconsecuente con las aspiraciones fundacionales de la enseñanza, entendida ésta, por un lado, como el campo en el que se articula la conservación del conocimiento históricamente constituido, en su encuentro con las dinámicas de la inestabilidad y la contingencia que le son constitutivas, y que llamamos saber (Behares, L. E, 2016), y por otro, como disciplina que ha de escudriñar y concurrir, con la función de educar como horizonte, en la aplicación, generación y uso razonable (personal, social y ecosistémicamente fiable) de conocimientos, saberes, conceptos, valores y actitudes (Arboleda, 2019).

Esta deuda se traduce, ni más ni menos, en antítesis del significado de la educación, que comporta el cometido de orientar esta actividad no solo al dominio conceptual y desarrollo de las áreas culturales, sino también, de acuerdo con 
Touriñán (2020 a p. 128), "al desarrollo transversal de los valores educativos generales que se vinculan al carácter y al sentido de la educación", lo cual en nuestra cosmovisión exige enseñar educando, cuestión cara a la didáctica como saber hacer de las enseñanzas que edu$\operatorname{can}^{17}$.

Aquí se advierten pasivos didácticos en la forma de concebir las relaciones exclusivas de y entre saber, ser, hacer y conocer. Estas se hallan hoy inspiradas, según se insistirá, menos o casi nada en fines humanizantes de la educación, y mucho más en la idea de formar seres con sufiencia para apropiar el conocimiento, saber usarlo y articularlo a sus vidas como actores de un proyecto de desarrollo global al que estamos supeditados, modelado por el embate del progreso que catapulta lo económico como el bien que ha de movilizar este proceso. Las crisis o catástrofes interconectadas, a saber climática, sanitarias, ecológicas, económicas, sociales, políticas, culturales y existenciales a las cuales estamos asistiendo, hacen permanentemente ostensible lo nefasto que esto ha representado para las esferas humana y no humana, a tal punto que el universo de la vida depende en buena lógica de los cambios que establezcamos para que el hombre y el planeta (el pluriverso o summun de mundos socionaturales, incluidos los micromundos singulares de cada individuo y comunidad interconectados e interdependientes) sean los motores del mejoramiento productivo, social, político, humano y demás formas. En esta apreciación las relaciones educativas no solo han de incorporar otras relaciones sino y sobre todo resignificar los elementos a relacionar, colocando lo humano, la vida y lo planetario como una di-

17 La enseñanza solo es enseñanza si educa. Para decirlo de nuevo con Comenio, siguiendo a Runge P., A. Klaus (2013), "no hay enseñanza que no eduque en algo". Estas premisas motivan la presencia en la PCE de la metáfora "enseñar educando" que traduce y constituye a la vez un principio pedagógico faltante en el universo educativo, pedagógico y didáctico. Toda buena enseñanza educa en algo, es decir apoya al estudiante en la formación de algunos potenciales para vivir y proceder en las relaciones sociales y ecosistémicas. alógica o interconexión entre lo humano, la multiplicidad de culturas, saberes y conocimientos, ahí los ancestrales, y lo no humano, un horizonte de sentido que insufla los procesos educativos, y alrededor de esa idea ennoblecer, o si es del caso reorientar la didáctica, la pedagogía, la epistemología, la formación y la filosofía de la educación. Cuestión que recorrerá en lo sucesivo de este texto.

Aunque en la actual didáctica hay indagaciones y propuestas reflexivas y metodológicas que intentan vincular el ser, el saber, la enseñanza, el currículo y los aprendizajes, procurando vindicar las connotaciones éticas y antropológicas de la educación, como es el caso de la didáctica crítica y de aquellos enfoques que enfatizan en el servicio y la cooperación, no lo hacen de manera abierta a la función de educar, y acaban empantanados en uno o algunos de aquellos a tal extremo que pueden terminar idealizando de manera excesiva el proceso educativo. Subsiste en la didáctica un faltante radical, de fondo en materia de enseñabilidad y educabilidad: su evolución y fines parecen ir a contrapelo con tal función, que entraña el reconocimiento y acogimiento del sujeto educable. Podría decirse que la episteme de educabilidad ha sido obnubilada, subordinada a la episteme de enseñabilidad que subyace a la didáctica y la escuela, subsumida a su vez, como las ciencias sociales y en general el saber, la civilización y la vida, en la episteme de la modernidad que acompaña al proyecto productivo prevaleciente, generador de las crisis humanas y planetarias.

Con tal pasivo la didáctica no ha debido poder aportar lo necesario al primado de la educación relacionado con cultivar el autoconocimiento -tanto el que analiza panoramicamente los propios desempeños en el marco de situaciones dadas, y sobre todo el que interpela por el ser: qué soy(siendo), cómo, para qué, por qué--, y el cuidado de sí mismo, de la vida y del globo terráqueo, operándose un divorcio, como con- 
secuencia del vacío radical, "esencial", entre didáctica, educablidad y educación, entre enseñanza y formación, entre aprendizaje y vida $^{18}$. Para lo cual es inobjetable que, fuera de dominar la materia, el docente ha de poseer e imaginar medios para el desarrollo de destrezas morales, éticas, sociales y constructivas en sus estudiantes y en sí mismo, sin las cuales la práctica de enseñanza colapsa en virtud a las bases endebles que sustentan su acción.

En esta apuesta la enseñanza no puede seguir representando el papel pasivo y acrítico de espacio de intervención, ni pretender hacer de los aprendizajes un evento para el almacenamiento e inclusive para una apropiación, generación y aplicación neutral o instrumental de conocimientos y conceptos. Por el contrario, la enseñanza ha de considerar que la educación es politica y que los aprendizajes son situados, no uniformes, lo que hace impostergable una didáctica emergente centrada en el espacio de la vida más que en los contenidos y aprendizajes que seducen al imperio del mercado perverso (que erosiona y deprecia cada vez más la vida en favor de la rentabilidad económica hasta un grado tal que se asegura de que ningún infante se quede por fuera del circuito comercial), un potencial humanizador que haga de los aprendizajes un ámbito de plurivocidad independiente, de cuestionamiento y generatividad ${ }^{19}$.

18 Divorcio que se acentúa con la invasión del mundo frágil de la vida a través del conocimiento del código genético y su digitalización en virtud del cual se altera ésta y se crean, más allá de la naturaleza (originaria), nuevas formas de vida, hasta un punto tal en que "el desarrollo de tecnociencias como la biotecnología, la nanotecnología, las tecnologías de la información y las ciencias cognitivas han cambiado el panorama de lo que se entiende por vida y corporalidad al situarse en el plano de lo molecular" (Riveros S., H.J., 2020). Es por ello que un aprendizaje comprensivo edificador (ACE) permitiría desvelar y quizás en parte atenuar los impactos de los desarrollos económico, biotecnológico y biopolítico en el ser humano, la vida y la existencia, que le han despojado de algunas de sus propiedades fundantes, e inyectado cada vez nuevas características, y a apartir de tal desentrañamiento ser ejemplo de su protección, si se prefiere de su liberación.

19 En este aspecto es diciente el planteamiento de Girox (2020), para quien los maestros son a menudo una amenaza para el Estado, porque tienen el poder de educar a la gente joven para que sepa hacer preguntas impertinentes (...), especialmente en aquellas sociedades que hacen todo
Optimar los aprendizajes fuerza reconocer (situar) las realidades cambiantes del sujeto y los contextos donde éste interactúa, y que tanto el aprendizaje como los sujetos y los entornos están signados por la contingencialidad, por dinámicas que no son inmutables, regulares, secuenciales, progresivas, claro fisgoneo en el devenir didáctico. Los aprendizajes no son un fenómeno que acontece por ósmosis, en el cual basta con que el mediador presente una información y de facto el estudiante la convierta en conocimiento (la enseñanza monumental, donde el profesor presenta el saber como si fuera una obra museográfica) ${ }^{20}$, sino que tienen un fundamento en la naturaleza biológica y cultural: en el sujeto que aprende pesa la condición de las funciones psíquicas que precisa este acto, entre otras las emociones, la voluntad, la consciencia, la motivación, la meditación ${ }^{21}$, los sen-

lo que pueden para transformar la educación en una especie de entrenamiento.

20 Este modo de enseñanza y de concebir ésta y el aprendizaje es denominado por Chevallard, monumentalización del saber. Al respecto Font (2003) sentencia que aprender no consiste en acumular información ni tampoco únicamente en investigar y solucionar problemas. Un aprendizaje significativo y funcional requiere, al mismo tiempo, la adquisición de conceptos y de procedimientos. Tal caracterización hace parte importante del que más adelante mencionamos como aprendizaje por comprensión, tanto como del que hemos denominado ACE.

21 Estudios más o menos recientes (Simon, 2014; Woloschin de Glaser y Serrabona, 2003; Arguis, Bolsas, Hernández y Salvador, 2010; Schoeberlein, 2011; Snel, 2016; Roeser, Skinner, Beers y Jennings (2012), entre otros mencionados por Palomero- Valero (2016) enfilan sobre los impactos del Yoga y otras prácticas de relajación, meditación, autoobservación y autoconsciencia, mal consideradas como pérdida de tiempo por ciertas teorías educativas, en las experiencias de enseñanza y aprendizaje, el rendimiento y el clima escolar. Prácticas que a nuesto modo de ver ayudan en particular a mirar viendo el propio universo interno de modo tal que nos permita dialogar y conectarnos con nosotros mismos, con nuestros congéneres y con lo no humano, avivando en el camino algunas funciones psíquicas imperiosas para el procesamiento de información tales como la atención, la voluntad, la motivación, la concentración, la imaginación, y para fortalecer otros hábitos y valores que apoyan el desarrollo académico, personal y social, y en consecuencia el saber ser, hacer y estar del individuo. Medios estos que se deben implementar sin vulnerar los intereses, derechos y otros aspectos favorables a la personalidad de los actores de la relación educativa, y que "no se deben confundir con filosofías esotéricas, con experiencias de aislamiento ni paranormales, o con estados de autocompasión, santidad y éxtasis inalcanzables para las personas corrientes, cuando no con una forma de escapar de la realidad, con el pensamiento reflexivo o, por el contrario, con no pen- 
timientos y las disposiciones; de igual modo las operaciones cognitivas, como las inferencias que estos usan de manera natural en su vida corriente y asimismo de manera deliberada en los aprendizajes escolares; tanto como el movimiento propio con el que cada sujeto asume los desafíos de aprender y de vivir. Orbita el entorno histórico, económico, politico, social y cultural de cada país y región, afectado por dinámicas de poder económico y político, propiamente por las visiones de estos en materia de desarrollo humano o rentabilístico, y la actitud ético politica de los individuos sociales para endogenizar y atender al otro necesitado, y para aprender a desaprender, para traducir de forma adecuada sus conocimientos y saberes en razón de usar estos y otros de sus recursos en la vida cotidiana y en la conquista de ámbitos de humanidad.

La didáctica descuida el hecho de que los aprendizajes son situados porque, además de lo que se acaba de relacionar, en muchas de sus aportaciones no es tan claro que estos no acontencen de manera progresiva e imperturbable, incólumes a las dinámicas contradictorias y complementarias de la naturaleza y la sociedad. Visión esta que emcumbra a una psicología del aprendizaje sembrada en la periodización, que ha marcado la práctica de la enseñanza en detrimento de los aprendizajes contemplativos (que no pasivos), comprensivos, generativos, críticos $y$ edificadores, $y$ en efecto de un reconocimiento y acogimiento adecuados del sujeto educable.

Es más, si bien las didácticas críticas dejan ver esta panorámica en sus planteamientos y propuestas teóricas y metodológicas, aspecto que reemprendemos más adelante, adolecen aún de elementos que conecten la enseñabilidad con la educabilidad para construir una significativa estructura relacional, que amalgame estos y otros conceptos pertinentes, para abonar al acto de enseñar educando, lo cual hace de esta actividad y de los aprendizajes un asunto ético político: tiene valor superior el aprendizaje si en sar en nada" (Palomero- Valero (2016). la práctica edifica, para lo cual son preciados los productos epistémicos, didácticos y pedagógicos que incluyen algunas de las consideraciones respecto a las enseñanzas y aprendizajes situados. No basta con ser crítico, pues esta actitud no es suficiente para fortalecer en el sujeto sus dominios cognoscitivos, socioafectivos y operativos en los aprendizajes y la formación; es necesario contribuir a la posibilidad de generar y usar aquellos con orientación generosa, valga decir al servicio de sí mismo, del otro y de lo otro. También acontece con las teorías y metodologías didácticas de corte semántico y por competencias ${ }^{22}$, entre muchas otras legitimidadas por las comunidades de enseñanza, incluidas las de nobles intenciones como la teoría de la ideoneidad didáctica expuesta por Godino y la teoría de las inteligencias múltiples de Gardner, entre otras que a decir verdad están basadas más en principios de rendimiento que auténticamente sentidos de la educación y por consiguiente son pasibles de ser puestas en función de una educación "rentabilista".

Hay suficiente evidencia en torno a que los saberes asociados a la docencia, el currículo, la didáctica y la evaluación no sirven, como se aprecia enseguida, una función edificadora,

22 Más adelante se abona a este asunto. Las perspectivas semánticas abogan sensatamente por una enseñanza que impulse en los estudiantes la construcción de significados y sentidos, tanto como sus homólogas, las de competencias, que encuentran en los desempeños de saber hacer el escenario apropiado para la resignificación. Una y otra superan los acercamientos que no permiten sacar a los aprendizajes del ostracismo de la quietud, más en su formulación no está explícito el propósito de enseñar educando ni de aprender siendo mejor ser; contextualizando a de Sousa Santos (2020, p. 39), hablan del ser pero no están con el ser. Las críticas de la PCE al enfoque por competencias que avala la episteme de la modernidad montada sobre la razón funcional y centrada en el individuo que rinde (que es eficiente pero que también honra al dinero) y no en el lazo comunitario que afirma a la humanidad y al planeta como espacio común, se refieren también a que este habla del ser y los valores del ser bajo la convicción de que las finalidades educativas y/o empresariales se alcanzarían de mejor manera con la actuación cooperativa, es decir que en la competencia necesitamos del otro. Pero en la ética no se trata de recibir del otro sino de dar-se al otro; los valores del ser en el modelo de la competencia se ajustan a las finalidades enmarcadas en programas de gestión del mercado, pero la vida humana precisa de valores originales, no utilitaristas. 
pues no atienden con responsabilidad los presupuestos de acogimiento, heterogeneidad y especificidad de sujeto y contexto ${ }^{23}$. Interpolando a Serres en alusión a los saberes y la escuela, aquellos siguen afirmándose como oferta, más no como demanda. Unos y otros deberían responder a los desafíos primarios de la educación, "escuchando el ruido de fondo surgido de la demanda, del mundo y de las poblaciones" (2012, P. 55). A pesar de que la teoría didáctica actual pone énfasis en estas consideraciones, de que hay esfuerzos por adelantar una sensible "antropología de los saberes ${ }^{24 "}$, y que en la actividad de enseñanza y formación el sujeto debe ser reconocido y acogido en su personalidad compleja, única, y en su realidad situada; que los actos de aprendizaje y formación pasan por el tamiz de lo probable y de lo posible; que es menester fortalecer la facultad analítica, crítica, indagativa y generativa en la escuela. Lo cierto es que en la práctica son menores las experiencias que logran corporizar estos enunciados proposicionales. Veamos algunas razones.

Por una parte, porque tal conocimiento didáctico no llega a todos los docentes, y poco se aborda en los programas e instituciones formativas el saber que indaga y aporta en los eventos de enseñanza y aprendizaje desde enfoques que van más allá de lo que ofrece la didáctica asituada, progresista y acrítica, y que no por ello se eximen del defecto de excesividad de formalismo y dogmatismo cientifista, o de un marcado relativismo epistemológico; por otra parte, porque la práctica monolitíca subsidiaria de perspectivas desafortunadas de la epistemología y la didáctica se ha instalado de tal forma en el currículo y la ar-

23 Es claro que el aprendizaje es un evento único, cada sujeto lo desarrolla en el transcurso de su existencia, sin ser necesaria siempre la mediación. Cada sujeto lo hace a su propio ritmo de procesamiento, con sus propias carencias $y$ virtudes, $y$ en las condiciones socio culturales, políticas e históricas de su trayectoria.

24 Expresión con la que Arboleda- Castrillón (2007) representan la actividad propia de la didáctica para reconocer la dinámica socio-histórica y la variación de los estados del saber (matemático) con el fin de aclarar el acto didáctico de intervención con el saber enseñado en clase. quitectura mental de los docentes y formadores, que muchos de estos no quieren salir de su pasiva zona de confort (no atienden la enseñanza como una misión social que implica pasión, entenderse de seres necesitados), y otros que presentan disposición para el cambio de paradigma no crean ni encuentran en sus acercamientos didácticos estrategias y metodologías "situadas" para el aprendizaje y la formación, que se correspondan con la nueva teoría que ofrece este saber, abortando en sus intentos. A lo anterior se suma, como una luz condicionante de las acciones de los actores educativos, el peso de lo cuantitativo, que define a la sociedad del rendimiento y aún se instala en dispositivos que afectan el aprendizaje y la enseñanza, por ejemplo la evaluación, cuya función social se sustenta ahora, desvanecida, más en la eficiencia de estudiantes, docentes e instituciones sometidas a la regulación, al cumplimiento de indicadores y metas estadísticas impuestas al sistema educativo por la ortodoxia de los poderes políticos $y$ financeros -- que al final se traduce en rendir cuentas --, que en la formación y mejora del aprendizaje, del educando y de la educación ${ }^{25}$.

$25 \quad$ La PCE aporta un enfoque formativo a la evaluación en las prácticas educativas. Parte de la idea que la evaluación, a diferencia del examen y la calificación, es sustantivamente edificadora: piloteada de modo conveniente no solo promueve mejoras en los aprendizajes sino crecimiento personal (del alumno y del mismo enseñante), colectivo e institucional, y afirma de paso el acto de enseñar educando. Un docente, una institución que educa evalúa de manera edificadora, es decir se acompaña de este faro para intervenir en la formación de aprendizajes que generen valores al desarrollo de la personalidad del escolar, haciendo de él mejor gente. En materia educativa una evaluación es realmente edificadora si se inserta en la conducta de acogimiento característica de quien educa, mejor de quien enseña educando. Para recibir al otro en las practicas de enseñanza, como condición de aporte en los aprendizajes, el docente ha de generar ambientes para reconocer al educando como otro, en su singularidad (sus conocimientos previos, intereses, contexto, estilos y modos de aprendizaje, entre otros aspectos de su pluridimensionalidad), y acompañarlo hasta donde sea posible en su crecimiento. No sería solamente un dispositivo para el aprendizaje sino también para la formación humana de los actores principales involucrados en el mismo acto. Examinar (determinar el alcance o no de los desempeños de construcción de saber siendo ejecutados por el educando, desempeños cognitivo-motivacionales, operativos y edificadores), valorar o reflexionar sobre estos (causas, consecuencias, otras razones), estrategias de mejora o fortalecimiento, y control del proceso, son 4 elementos interdependientes que configuran la evaluación y que el docente ha de portar en su propia práctica de acogimiento, 
Y también, porque la institucionalidad no está realmente interesada en una enseñanza y formación que discuta la racionalidad que cobija intereses del régimen dominante, para los cuales la educación que edifique resulta altamente peyorativa, sino en una educación instrumental, controlable y técnica, es decir inspirada en el modo de hacer por encima del modo de ser, que forme sujetos reproductores del modelo occidental de desarrollo globalizado que cada vez agudiza las crisis de energía/ clima y pobreza, entre otras, y no individuos críticos de un sistema que abusa del planeta, que atenta contra los los derechos humanos, el derecho a una vida y muerte con mínimos de dignidad, mínimamente humana. Ilustración paradigmática de ello es la ausencia de un currículo, una didáctica y una evaluación sincronizados para que realmente edifiquen, lo cual diezma del mismo modo el accionar de los individuos de la relación educativa y pedagógica que apuestan por la construcción de espacios de libertad para el complejo educativo.

No sin razón y en materia de las deudas radicales de la educación y la formación, y de la desorientación didáctica y curricular, De la Herrán (2019) manifiesta el imperativo de reenfocar completamente la formación del profesorado, y por tanto la didáctica en tanto "ciencia de la formación", "núcleo de la pedagogía". Con ello asegura que asistimos a una Didáctica incoherente, en tanto epistemológicamente reinan muchas ideas pedagógicas y didácticas cuya legitimación no estimula su confrontación, la autocrítica, el autoconocimiento, la auto observación y disposición a rectificar, dejando por el camino la tentativa de renovación pedagógica. El enfoque radical e inclusivo sugiere que la Pedagogía y la educación se desarrollan "en la

y junto con aquel en el proceso de aprendizaje y formación. (Arboleda, J. C. 2011b). Más que una función mensurable, la evaluativa es de carácter formativo, mejor edificador, que obliga a la didáctica y al currículo a reinventar, modificar y actualizar sus reflexiones y estrategias. parte visible del árbol, en la porción emergida del iceberg o en la cara cercana de la Luna, y no por tanto en la complejidad y compleción del ser y del fenómeno" (p. 25). En materia de formación docente sostiene que esta puede pensarse y direccionarse (reorientarse) desde temas radicales sobre los cuales podrían gravitar las apuestas epistemológicas educativas, asuntos que atañen con el ser y su interior, y que se revelan como retos originales que la educación, la pedagogía y la didáctica han relegado por privilegiar la reflexión y el pensamiento crítico en torno a la práctica y el devenir de la educación, las capacidades, habilidades y destrezas, todos los cuales hacen parte de la externalidad del ser, representan efectos y no la raiz de la enseñanza, que tiene que ver más "con quien realiza la práctica, con quien piensa, con su conciencia y ego docente": por ejemplo, desde la interiorización, la consciencia del ser esencial, el autoconocimiento y la meditación "como antesalas y metodologías ancestrales de la formación profunda, con un apreciable respaldo experimental" ( $P .38$ ).

Podría decirse que la actuación didáctica ha corrido al compás rítmico de estas ausencias en la enseñanza y los aprendizajes, siendo pasiva frente a las exigencias de enseñabilidad y educabilidad focalizadas, y en consecuencia frente al agregamiento institucional, intencional de estos eventos. Lo que prima en las teorías y prácticas de enseñanza es su incidencia en los aspectos académicos e intelectuales, como si de esta manera se formaran mejores seres humanos, fisgando los aspectos afectivos, emocionales, incluyentes y de acogimiento, los ritmos y modalidades de los sujetos para aprender y actuar con lo que saben y conocen, así como la naturaleza variable de los acontecimientos de formación, aprendizaje y enseñanza. Para decirlo con Dogliotti (2012), la enseñanza se circunscribe a un componente de intervención, traduciéndose la relación enseñanza-aprendizaje en un guión 
que se supone pleno de significación, propio de las teorías modernas.

Así, seguimos asistiendo a una didáctica academicista, que corona los aprendizajes y mira sin ver la educabilidad ${ }^{26}$; una muestra más acaso de la sumisión del saber al poder económico político ${ }^{27}$. En este segmento tiene razón Behares (2004) cuando hace visible, encima, que hay una sujeción demasiado evidente de la investigación didáctica a la inmediatez de las prácticas escolares, con una frágil consciencia básica (o crítica) de las cuestiones epistémicas y teóricas que las subyacen.

Pero si autores como éste destacan una deuda epistemológica como la que se expone, los hay como Ortega (2020), Arboleda (2001; 2007) y sobre todo De La Herrán (2018, 2019), quienes cuestionan epistemológicamente el pensamiento educativo y didáctico que sobredimensiona, por una parte, el saber, invisibilizando el no conocer, el no saber, el autoconocimiento y las apuestas de vida aparejadas a estos actos de aprendizaje y crecimiento personal ${ }^{28}$. $\mathrm{Y}$

26 Si bien no se condice aquí con la noción que Herbart otorga a la educabilidad como atributo específicamente humano, concepto centrado en el sujeto educable, que fija enseñanzas situadas, aquí lo utilizamos analogamente del lado del docente, enmarcado en la función de educar: todo ser humano es educable, pero la función de educar es responsabilidad de la escuela y de las instituciones sociales, de asumir y darle cuerpo a la educabilidad desde la actitud de recibimiento y acogimiento, que pasa por reconocer y habitar la situación cambiante del sujeto y el contexto en su unicidad -- aspectos estos que hacen parte de las condiciones de educabilidad -- en el modo que a lo largo del escrito se propone.

27 ¿No tendrá lugar acaso hablar de la institucionalización de la didáctica, en la idea del enfilamiento de su acción bajo los cánones que impone el régimen social y sus poderes económico políticos? O de lo contrario, la didáctica como entidad emergente, independiente, mayor, incorruptible. Institucional. Que logre marcar pauta a los saberes y prácticas de enseñanza, formación y aprendizaje de vista a los fines primarios de la educación?

28 Según de la Herrán (2018), lo que en nuestra educación (la pedagogía, la didáctica, la epistemología y en general sus saberes asociados) se entiende por saber tiene que ver con contenidos, conocimientos y su empleo para la vida, las sociedades, la cultura, las profesiones, la investigación, el comportarse, el ser, etc. (...) También somos no ser, somos lo que ignoramos, se sea consciente de ello o no; somos lo que conocemos y lo que no sabemos, somos y no somos, lo que adquirimos, lo que perdemos o soltamos y lo que queda. (...) La educación se ha distan- por otra, sublima la reflexión y el razonamiento consciente, como si este proceso mental, cuya necesidad no se objeta, fuera suficiente para el cambio educativo, o para lograr las finalidades de la enseñanza y la formación. Respecto a la necesidad de compasión y acogimiento del otro en el acto de la enseñanza, como respuesta ética perentoria en los actos de enseñar y educar, Ortega enfatiza lo siguiente: "No nos compadecemos del otro porque hagamos sesudos razonamientos sobre la dignidad de la persona, sino por el 'vuelco' interior que nos produce su situación de necesidad significada en su rostro herido".

Una tarea importante de la didáctica y en general de la escuela es generar espacios para educar la mirada que nos abra a ver más allá de las pantallas del teléfono, la computadora y el televisor, para apreciar lo que a simple vista no vemos en la trayectoria laboral, familiar, escolar o cotidiana. Alcanzar la mayoría de edad en la mirada es ya una manera de aprender a mirar viendo, si se prefiere, aprender a ver mirando, a ver y mirar reparando, a ver flexibilizando (dignificando) la percepción. Ese debería ser uno de los fundamentos de la formación de niños, jóvenes y adultos. Solo se educa en la pluridimensionalidad del ser humano, que incluye las funciones de las mentes racional y no racional. Educar la mirada implica al pensamiento, acompañar la mirada rutinaria de un ojo avizor que posibilite ver, por una parte, a través de operaciones reflexivas, cognitivas y metacognitivas que abonen en la construcción de sentidos y significados a lo que hacemos, a la manera como vivimos, como sentimos, como actuamos y estamos siendo, como resolvemos o dejamos de enfrentar los conflictos, las dificultades, las infelicidades, frustraciones, psicosomatismos y otros retos de vivir; y por

ciado de sí misma. Pensamos aquí que, por ese motivo, centrar la educación en el saber o el conocimiento es un oxímoron, como lo es una formación basada en competencias, en objetivos o en todo lo que no sea la conciencia y el autoconocimiento. 
otra, contando también con algunas de las funciones psíquicas, juzgadas irracionalmente como submente, el sentimiento, las emociones, la meditación, las corazonadas, la intuición, la percepción, la disposición a ver con otra mirada, desde fronteras no predeterminadas. Implica funciones psíquicas racionales y no racionales. Implica la experiencia, el desafío de transformarnos, de reinventarnos, de quebrarnos, de ser otros; pasar de la mirada unilateral a la mirada plural, flexible; del monolitismo a la flexibilidad y autenticidad de la percepción y del pensamiento ${ }^{29}$.

Valga la siguiente aclaración. No se empaque lo expresado alrededor del sobrepeso que en la didáctica ejerce la razón, en las posturas que minimizan aquella ensalzando la mente no racional; nos interesa que la didáctica se reinvente afirmando una razón y una no razón más incluyentes, dialógicas, que acoja en su magnitud al sujeto educable con sus atributos racional y no racional. Precisaría en su reconstitución una nueva razón. Para decirlo con Serres, "una nueva razón, acogedora de lo concreto singular", que no excluya lo que considera un desatino, un desorden, un disparate, pues "lo disparatado tiene virtudes que la razón no conoce" y "en el desorden entra aire" (p. 60); una nueva razón que participe en el proyecto de reconocimiento e implicancia que demanda la construcción y afluencia de conocimientos y saberes.

Alcanzamos entonces otro rasgo que caracteriza a la didáctica y la enseñanza modernas, y que ya hemos develado aquí: la incorporeidad de alteridad presente en la episteme dominante, faceta que ahonda el maltrato a la educabilidad en estos eventos, y que cubre la práctica educativa al no estar soportada en relaciones de otredad, es decir en el nexo de los sujetos de la

\footnotetext{
29 Una educación auténtica promueve la construcción de una mirada emancipada en el sujeto, lo más independiente posible, que desafíe el proyecto absolutista que globaliza, dispone de nuestros sentimientos y demás funciones psíquicas.
}

relación educativa consigo mismos, con el otro y con lo otro ${ }^{30}$. Sirva recordar que la educación, al igual que la ética, referente que la atraviesa junto con la antropología, es un encuentro con el otro que nos demanda acogida y reconocimiento (Ortega, 2020). Cuestión esta que corrobora el desamparo que cada vez se acentúa en todos los seres que habitan el universo ecosistémico, incuidos los actos de la educación, en particular el sujeto educable que no encuentra en el docente y agentes educativos actitud de recibimiento, núcleo de la alteridad.

Embebidas en la enseñanza técnica las reflexiones y aportaciones de la didáctica no deberán poder contribuir decididamente al impulso de los valores subyacentes a la acción educativa, empezando por el mismo conocimiento, cuya construcción y reconstrucción sólidas precisa partir de las relaciones entrañables entre la ética, la antropología y la educación, que no ha de desconocer tampoco la didáctica. Los valores éticos del reconocimiento y la interiorización del otro están, aún de manera críptica, en la base de la mediación de las enseñanzas escolares, pues la intervención en la apropiación semántica de un conocimiento y en general en la formación educativa requieren de estos. Un $30 \quad$ Nuestro sí mismo viene cargado semánticamente desde antes de nacer, es epistemizado, pues no dejamos de asistir a lo que Foucault (1983) Ilamó periodos enunciativos, de voces que dejan oir las entonaciones del capitalismo financiero en el cual se funde y confunde la episteme dominante; poder y saber imbricados mutuamente, inexorablemente depredadores, deshumanizantes, agregacionistas del otro y de lo otro que construye la existencia, y que esta duo-deidad (si se me permite la expresión), impide por todos los medios que corporicemos para nutrirnos como mejores seres humanos. La lógica del saber - poder financiero define las formas contemporáneas de dominación; se asume como el otro único, hegemónico, una universalidad unidireccional que impone su saber, su pensamiento, colonizando otras formas de pensar, percibir, creer, sentir, actuar, obrar y ser, ensimismando en el letargo de la ausencia a la otredad. Se trata del Dios saber-dinero omnipresente en el otro y lo otro, que se opone a cualquier programa para vivir y educar en la alteridad ética. Por esta razón es necesario inundar de ésta los ámbitos escolares, familiares, laborales, sociales, cotidianos, para cargar de sentidos otros nuestros sí mismos, independizándonos del único egoepistémico, epistemicida, egoepis que somete a su arbitrio al tejido de mundos humano, de la vida y planetario, y de esa forma permitir que devenga una nueva episteme, una episteme humanizante, comprensivo edificadora en virtud de la cual aprendamos a saber ser otros. 
tratamiento antropológico es inexorable en la acción educativa y por tanto la enseñanza ha de partir del sujeto y del contexto, que no son homogéneos ni rectilíneos ni estáticos, son por el contrario excepcionales: cada sujeto educable tiene necesidades educativas distintas porque cada sujeto es único, peculiarmente impactado por los cambios sociales y globales en materia ecológica, económica, cultural, política y demás, lo que exige a la enseñanza consideración y hospitalidad situadas. Los procesos de homogenización promueven una enseñanza a debe, que ignora que cada entorno en que deviene un individuo es tan singular como este mismo; cada individuo tiene sus propios ritmos, armonías y desarmonías, estilos y modos de aprendizaje, intereses, experiencias y afectaciones específicas, cuyo desconocimiento harán abortivas la enseñanza y la didáctica; una enseñanza que, al ignorar la realidad y circunstancialidad concreta de cada ser, se hace inmediatista, vulnerable a los ritmos y lógicas efímeros de los sistemas económicos y políticos.

La compleja tarea ética de abrazar al sujeto educable en la relación educativa demanda, según la pedagogía de la alteridad ${ }^{31}$, la actitud compasiva de vivir como propias las carencias y demandas del otro, sentir como propio su sufrimiento y dolor, conductas estas que nacen de las entrañas y no exactamente de la razón. Un argumento que reivindica Ortega (2020, p. 27) es que, desde el punto de vista de la ética ${ }^{32}$, es el otro, en su necesidad, quien legisla y ordena (...), me hace responsable de él sin que pueda decidir aceptarlo o rechazarlo. (...) Esta ruptura o abandono del bien propio obliga inevitablemente al individuo a ser dependiente, rehén del

$31 \quad$ La perspectiva pedagógica de la alteridad que propone Pedro Ortega a partir de la ética levinasiana, aporta reflexiones e ideas, algunas de las cuales cobran vida en este documento, para desarrollar "otra educación moral", orientada a "Educar para responder del otro que "llevamos dentro' y nos constituye en sujetos morales" (Ortega, 2020).

32 Vista, según Ortega (p. 27), "como atadura que nos liga irremediablemente al otro", "y que atraviesa la educación de inicio a fin, haciéndose presente en cada uno de sus actos. otro en su misma identidad humana" (...). Soy sujeto cuando me siento atado al otro con una responsabilidad que no me la puedo quitar de encima, que ni la he buscado ni procede de un acto de mi conciencia". La ética define aquí la noción de sujeto, como ser atado al otro, aunque no determina el carácter de la sujeción, sea como abandono del bien propio como considera Ortega, o, en nuestro caso, como la disposición a compartir (no a la renuncia de) nuestros potenciales: el sujeto se entrega al bien propio y al bien común, sin renunciar a ninguno de estos.

Como se sabe, en el orbe educativo domina el carácter técnico, sólo interesa el desarrollo de competencias, incluidas las de relieve ciudadano pragmático: aquellas que sirven la finalidad de prosperidad material. Para decirlo con Serres (2012. P. 21), asistimos a "una sociedad en la cual la competencia aplastante, vanidosamente inculta, eclipsa la institución escolar". El desempeño, el hacer del sujeto es la prioridad, que socava al ser. La escuela y el docente fríos, insensibles, "competentes" no pueden tocar el alma del estudiante, capturar en su espíritu la dignidad de cada educando. Sólo alcanzan a lograrlo quienes apropian el acto de educar como un parto edificador, lo cual se logra, como se verá, cuando la institución educativa "concibe" educadores que a su vez incuban en su propio seno al educando necesitado de educación y formación, y requiere aprender de manera permanente a reconocerlo en su unicidad, intervenir de modo idóneo en la construcción cognitiva, metacognitiva, operativa y personalizante de conocimientos, en la formación de valores y actitudes por la vida -- no justamente para el mundo de hoy, inmensamente reluctante en calidad de vida --, implica habitarlo en su fragilidad y necesidad (sentirlo como su propia piel, protegiéndose a sí mismo), sin dejar de observar y analizar el proceso de manera consciente y crítica, propositiva y actuante $^{33}$. Observar y asumir teórica y metodológicamente este aspecto en la didáctica,

$\overline{33 \quad \text { Arboleda }}(2015 d)$ 
haría quizás de este saber una praxis sentidamente transformadora.

Desafortunadamente la praxis didáctica moderna no ha logrado constituir una fuerza edificante en las prácticas de enseñanza. Para serlo, las finalidades del sistema social y político afable a la esfera del mercado deberán sintonizarse con actitud crítica y generativa en éstas y en el acercamiento didáctico, tanto como las aspiraciones más genuinas que se tienen desde la educación, y en general en los saberes científicos, contrastando una y otra. Así mismo, el aparataje conceptual y metodológico de una didáctica virtuosa habrá de erigirse sobre la mirada consciente y acontecimental de la realidad social donde se naturaliza el hecho de que los sistemas educativos y los organismos internacionales que deciden la educación ponen en práctica modelos educativos y didácticos cuya base común no ha de condecir las pretensiones del régimen global, que en aras de dar vía libre al capital financiero global termina normalizando la exclusión, la homogeneización, la inequidad y el desamparo.

Nuestra percepción en torno a la episteme de la didáctica moderna, compartida por autores como Behares (2004), De la Herrán (2019) y Bordoli (2005), entre otros, revela el requerimiento de construir una episteme independiente en lo posible de la episteme de la modernidad, una episteme sentida -- que deje escudriñar los radicales de la enseñanza y la formación basados en la apropiación de saber para ser otro, mejor ótrico, una mejor persona --, una episteme CE sembrada en la piel del ser vulnerado vivo y no vivo, que haga de la didáctica no un acicate para eternizar los órdenes que sistematicamente generan injusticia, pasividad en los individuos y desigualdad económica, social y hasta digital, que constrine la construcción de subjetividades, marcando punzantemente sus acciones y actuaciones en los recodos de sus vidas, sino una disciplina que a la luz del sentido humanizante de la educación y de criterios democráticos sobre las necesidades comunes e individuales, promueva la edificación de nuevas subjetividades (primeramente en el profesorado) con la actitud ética de denuncia y afrontamiento creativo a los perjuicios y prejuicios históricos de la racionalidad imperante, y en general para relacionarse consigo mismo, con el otro y lo otro, y en consecuencia aprendizajes situados, realmente sensibles. Se hace imperioso operar un cambio epistemológico, formativo y docente, en concordancia con la necesidad de que los estudiantes aprendan y se formen con rigor comprensivo y sentido; para lo cual habría que derribar muros de acercamientos a la didáctica que han sido legitimados como conocimientos definitivos y dogmas.

En esta vista sobre el rumbo que toma la actual didáctica podemos advertir el horizonte de las enseñanzas que demanda la civilización de la vida y sobre el cual ha de discurrir una didáctica (y por supuesto una pedagogía) humanizada ${ }^{34}$, para obrar una rebobinación a los procesos intervención que promueve la economía salvaje (atada a la política y los valores prevalecientes), que involucre a los sujetos del acto pedagógico en procesos de apropiación, generación y aplicación contextualizada de conocimientos y saberes, básicos para el desarrollo social y económico de las naciones, pero que, además, exija el uso consciente y edificador de estos, de

34 En armonía con la idea de humanización, la humanización de la didáctica residiría, por consiguiente, en la incorporación de la función de educar y de los principios de responsabilidad y respeto por la vida, la dignidad humana, el otro y lo otro en los abordajes que realicen los saberes didácticos y el campo didáctico que pretende articular y dialogar sobre estos últimos.

De igual modo, la humanización de la educación consistiría en el acontecimiento deseable mediante el cual se ha de reorientar, bajo preceptos edificantes, las concepciones, ideales y prácticas de los sistemas educativos, y de las disciplinas y asignaturas escolares. Estos conceptos han de resituar la función de educar en sus justas dimensiones, y también incluir reflexiones y comprensiones críticas y sentidas sobre los fenómenos de conmoción educativa y planetaria, a la luz de interrogantes como las que formula Riveros (2020): “¿Cómo construir elementos para el análisis crítico y la consolidación de procesos educativos en el contexto de los desarrollos de la biotecnología y los retos que emergen a partir de la transformación de la vida entendida como información, a causa del avance de la digitalización de la existencia como consecuencia del desarrollo de las tecnociencias contemporáneas?". 
valores, ideas y creencias adquiridas, así como la promoción de desempeños determinantes para hacer de los aprendizajes un activo para el cuidado, preservación y evolución de la vida y de los ecosistemas. En palabras de Bourdieu, P. (2000 a): "una enseñanza capaz de "deseternizar lo dado".

Visto así, una didáctica humanizada ha de retomar las indagaciones que se descentran de marcos rígidos que van en contravía del movimiento contingente del hombre, de los procesos socio culturales y ambientales, y de la vida; es el caso de investigaciones como las de Pushe (2018), entre otros autores, que perciben, más que procesos cognitivos cambios cognitivos, y más que periodos transiciones; ponen de presente que el cambio cognitivo en los funcionamientos inferenciales implicados en la resolución de algunos problemas no sigue una trayectoria frontal de avances progresivos y secuenciales. Pues una didáctica humanizada no desafina con las realidades complejas de sujeto y contexto, no las silencia; por el contrario, parte de estas para que la enseñanza camine con el educando en su empoderamiento como sistema vivo con don de gente, para que participe en la gestación de una ciudadanía global y sea artífice de una construcción social más digna. Que no haga del currículo un constructo basado en los controles y estratagemas, los tiempos fugaces, lineales y discursivos que establece la modernidad capitalista para la gestión productiva, como si el conocimiento, los aprendizajes, la pedagogía y la formación no discurrieran de acuerdo a sus propias secuencias, ritmos, contingencias y discursividades, sino un instrumento con una historia ondulante, un discurso de configuración inestable que se modifica según la actividad táctica de los distintos actores del hecho educativo.

En armonía con la idea de humanización expresada, la humanización de la didáctica residiría, por consiguiente, en la incorporación de la función de educar y de los principios de responsabi- lidad y respeto por la vida, la dignidad humana, el otro y lo otro en los abordajes que realicen los saberes didácticos y el campo didáctico que pretende articular y dialogar sobre estos últimos. De igual modo, la humanización de la educación consistiría en el acontecimiento deseable mediante el cual se ha de reorientar, bajo preceptos edificantes, las concepciones, ideales y prácticas de los sistemas educativos, y de las disciplinas y asignaturas escolares.

Esta didáctica (vitalizada) avanzaría sobre caminos abiertos y no uniformes, homogenizantes y por tanto excluyentes como supone aquella, para intentar relumbrar con calidez los procesos de enseñanza que caracterizan la educación contemporánea, la cual aún concibe el aprendizaje humano, según hemos dicho, como un proceso objetivo, controlable, y un desarrollo cognitivo basado en la periodización, en secuencias verticales tipo causa- efecto, en competencias y desempeños prefijados para el rendimiento personal y encalados falsamente como conductores de crecimiento del ser, actuaciones que deben ejecutar los individuos supuestamente para poder progresar, bajo tiempos consignados en las planeaciones que deben corresponderse con las temporalidades que instaura el desarrollo global, sin considerar las diferencias y movimeintos propios del entorno y del sujeto, en este caso sus ritmos, estilos y modos de aprendizaje, sus creencias, motivaciones, fracasos e intereses. La nueva didáctica respondería a la realidad empírica de la educación, el sujeto, el contexto social, cultural, político, de la vida y la existencia -- uno y otro molecularizados, alcanzados por la máquina incesante del progreso biotecnológico --, en lugar de caer cada vez en el pozo de las industrias tecnológicas, científicas y académicas donde yace la enseñanza y la escuela dirigidas por la economía de los negocios que impone sus propios criterios, comportamientos y modos de organización; en lugar de apoyar al control de la trazabilidad del modelo imperante por la institucionalidad y el proceso 
educativo, a través de la planificación y los instructivos que deben diliigenciar los maestros y directivos de la educación.

La mayoría de edad, autonomía o soberanía del pensamiento didáctico debe correr paralelas con la función de educar y el sentido de la educación, que aboga por la edificación de seres con propiedad de acogimiento, compasivos, constructores de espacios más dignos para sí mismos y para la vida humana y cósmica. El pensamiento didáctico no puede ser vulnerable al influjo de intereses que riñan con la función referida, o que tengan a la didáctica, la enseñanza y el aprendizaje como palancas al servicio de los mismos, tiranizadas por la idea concretada de la utilidad.

De esta manera prima pensar de manera edificadora y actuante, en lugar de pensar institucionalmente, es decir, instalados, para decirlo con Heclo (2010), en un campo normativo preexistente que tiene como finalidad guiar las elecciones de los agentes al interior de la institución en cuestión, con independencia de sus preferencias privadas. Esta proposición interpela el carácter instrumental en que ha devenido la didáctica, al confinar sus estudios a los procesos de enseñar y aprender, basándose preferencialmente en los desarrollos de la psicología del aprendizaje desde las visiones cognitivistas, constructivistas y conductistas ${ }^{35}$. No es interés fundamental de estas la apuesta de formar mejores personas, sino, como se ha dicho, sujetos competentes con los atributos necesarios para apropiar, generar y aplicar los conocimientos; como si el saber y el conocimiento per se fuesen el fin, o acicates para la productividad y la rentabilidad traducida como acumulación sin fin, ideas que aún laten o corren solapadas en la episteme moderna. Al respecto, la PCE y las perspectivas humanistas y esperanzadoras que la enriquecen propenden por inyectar cono- cimientos pedagógicos y didácticos dirigidos a vigorizar los acercamientos, prácticas y praxis sobre los procesos de conocer, enseñar, aplicar y crear conocimiento con conciencia condescendiente con la vida, la existencia y el hombre.

Al respecto, valga preguntarse: ¿Qué diferencia hay entre abordar tales procesos con y sin finalidad edificadora? La experiencia ha demostrado que la didáctica ha ido construyendo unos límites en la edificación de su dominio, en los cuales su función no se conecta con la función de educar, que por principio es transversal al acto educativo. El sentido edificante de la educación y de esta función, que corre al unísono con el uso bondadoso de fortalezas como el conocimiento, no parece ser del resorte de la didáctica. De tal modo esta fluiría desligada de la noción de educación como acontecimiento ético donde cada ser es responsable como otro del otro y por el que el educando debe ser acogido: reconocido y abrazado en su singularidad cambiante, a fin de que proceda como persona interesada en sí misma, en sus congéneres, en la vida y la existencia. Cuestión esta que escenifica un conflicto de resorte antropológico y otro epistémico.

El primero aletea en torno al individualismo, reafirmado por un exencionalismo antropológico que prevalece en nuestras relaciones educativas, económicas, sociales y planetarias, y que se afirma a través de la negación del otro (la imposición del yo unitario y autoritario), barnizando el carácter social y ambiental del sujeto, la naturaleza intersubjetiva y ecosistémica de la vida humana: ignorando que somos sociales, que como sujetos dependemos de lo colectivo para existir, para ser lo que somos o estamos siendo; pero que también nos debemos a la dimensión ambiental, mejor ecológica, que nos compromete con la tierra, con la interconexión entre lo vivo y no vivo. El segundo conflicto está marcado por el faro (solidario o lucrativo) que guía la construcción y uso de conocimientos y saberes, de valores, motivaciones y actitudes; dominado 
por una episteme centrada en el individuo y la prosperidad económica, y no en la persona, la vida y la evolución humana.

De ahí nuestra crítica propositiva a los saberes ligados a la educación (allí la didáctica) en razón a su "ensimismamiento", al olvido de su misión de potenciar la construcción de visión de mundo y de vida en las prácticas de enseñanza, que se expresa en las escuelas y maestros que enseñan pero no educan (se embriagan en los aprendizajes dilatando el encargo de enaltecer el ser ecosocial del hombre), como en quienes ni enseñan ni educan, y quienes forman para el mercado en lugar de formar para la vida y la existencia.

De acuerdo con estos planteamientos, los desarrollos de la didáctica han de dar un lugar relevante a enseñanzas y aprendizajes para la vida tales como los Comprensivo edificadores (ACE). El ACE constituye, como se explicita en el apartado que sigue, el acto mediante el cual un sujeto logra apropiarse de un objeto de conocimiento (sea un tema de clase, una lectura, un discurso verbal o no verbal, entre otras entidades reales, ideales o imaginarias), y a partir de éste realiza aplicaciones, vivenciaciones, meditaciones, interpretaciones y reflexiones críticas y contextualizadas, generando nuevas ideas o conocimientos que se usen, al final, para el servicio del hombre y de la vida. $Y$ la enseñanza (ECE) sería el acto de acompañar ética, ótrica y estratégicamente al educando en esta tarea ${ }^{36}$. Quien aprende de este modo no solamente forma conocimientos para procesar información, es decir para realizar, de acuerdo a su ritmo y demás rasgos propios, operaciones y procedimientos tales como organizar aquella que trata (que escucha y lee en clase o fuera de esta), identificar, explicar y explicitar ideas, jer-

36 Ótricamente significa aquí de manera acogiente, no solo reconociéndose como otro distinto, sino sabiendo serlo. Ser ótrico es ser realmente otro, es asumir la actitud de incluir al otro y lo otro en sus intereses, disposiciones, comprensiones, potenciales, acciones de vida en el espacio común que constituyen los mundos humano y no humano. arquizando estas, entre otras acciones, sino que por otra parte desarrolla hábitos, habilidades, destrezas, disposiciones y actitudes para confirmar y evaluar de manera permanente sus progresos o retrocesos, usar sus conocimientos y generar nuevas ideas, ahondando en el proceso de manera pausada, analítica, crítica y actuante. En materia de comprensión y producción textual la PCE diferencia las tipologías comunes, propone el nivel edificador de la comprensión, y utiliza los mecanismos de cohesión y coherencia significativos para construir y desarrollar los significados y sentidos que requiere el material que han de apropiar, leer y/o escribir (Arboleda, $2019 b)^{37}$. La metodología CE incluye el nivel en referencia.

Es sensato reconocer de manera recurrente que el sentido primario del acto de educar es

$37 \quad$ Desde la perspectiva comprensivo edificadora (PCE) hemos propuesto el nivel edificador, complementario a los niveles literal, inferencial y crítico que se reconoce en el escenario comprensivo y discursivo. "Para que opere este nivel comprensivo es necesario que acaezcan movimientos interconectados aunque no lineales de desempeños de tipo cognitivo- conceptual y operativo edificador de sí mismo, del otro y de lo otro, pasando por la contemplación activa como ejercicio ontológico y axiológico, y la reflexión crítica y propositiva de la realidad y sus circunstancias, o lo que supone Godino y otros (2012) en su teoría de la identidad didáctica: una reflexión sobre lo que hace con relación a lo que piensa. Este nivel tiene sentido a partir de la noción que se maneje de comprensión. Desde la PCE la comprensión de un hecho, por caso, demanda, por una parte, dilucidar éste, esclarecerlo, interpretarlo, entenderlo; así mismo, vivenciarlo, ser artífice de experiencias transformadoras a partir del mismo, que constituyan acontecimientos que afecten al ser personal del sujeto comprendedor y al entorno. Nadie comprende realmente su sociedad, si no la interpreta $y$, paralelamente, participa crítica y activamente en los conflictos sociales, actuando con fuerza en favor de su desarrollo no violento y humano; he ahí un ejemplo paradigmático de experiencia humanizante, a mi criterio, una cualidad relevante de la comprensión. Nadie comprende efectivamente algo, sea un tema de estudio, fenómeno o situación (ahí la vida y la muerte, el vivir y el morir), si, aparte de entenderlo e interpretarlo (procesarlo afectiva y cognitivamente), no lo aplica y usa en contextos flexibles, incluido su contorno personal y social, reflexionando sobre tal experiencia, con la pretensión de que ésta devenga un estado que provoque en el sujeto y el objeto transformaciones, además de los nuevos discernimientos de comprensión, que, al final, independientemente de las fortunas o incomodidades que advengan en el proceso, son siempre provechosas"(Arboleda, 2019b p 17). Si desde este nivel la afectación personal y del entorno (la totalidad de objetos que constituyen la existencia, reales, ideales e imaginarios) es afirmadora de los mundos humano y no humano y de su interrelación, estamos ante una comprensión edificadora, sabia. 
promover la formación de seres éticos, ótricos que empoderen su vida para contribuir al crecimiento del hombre, la edificación social y la evolución de la vida. Como colorario, toda educación ha de ser genuinamente sentida, edificadora, por lo que educar para fines ajenos a la evolución humana y de la vida constituye una paradoja. En esa vía los procesos que la educación, como derecho humano, exige para cumplir su finalidad (y por extensión los dominios, perspectivas, enfoques o modelos que proyectan estos) han de estar conducidos por un sentimiento edificante; es decir, los actos de conocer, saber, ser, enseñar y educar, entre otros, han de establecer relaciones recíprocas, con espíritu de humanidad, agregando valores diferencialmente sensibles. Soslayar esta función y anquilosarse en sus fines específicos representa un pasivo con graves efectos.

Uno de estos es que la didáctica, el currículo, la evaluación y la misma pedagogía son cada vez más endebles frente a los poderes económicos, políticos e ideológicos, en particular frente a los intereses deshumanizantes que gravitan en la era global (que crean y moldean relaciones, estructuras, identidades y jerarquías), obcecados en configurar sujetos y subjetividades porosas. Hasta el punto de que una proposición nuclear en la PCE es que hoy la educación sirve más los propósitos de los negocios que de la vida. Las fuerzas del consumismo instantáneo, de sensaciones pasajeras, basadas en la lógica (en la ley) del retorno económico, fijan presupuestos que se incuban en el proceso educativo, orientaciones educativas, pedagógicas, curriculares, discursivas y evaluativas para el procesamiento veloz y homogéneo y no detenido y singularizado, así como el uso utilitarista y no edificador de saberes y conocimientos, de actitudes y valores. Para decirlo con Serres (2012), "hemos externalizado nuestra educación y saberes, y los depositamos en los engranajes y dinámicas del mercado y los bloques dominantes", que reafirman este sistema o modo precario de vida que cada vez nos hace seres desprotegidos, necesitados.

Prueba de ello es el darwinismo educativo que hoy impera, producto del agenciamiento educativo para el rendimiento financiero que subyace al enfoque por competencias, impuesto a los sistemas educativos por el poder omnímodo de un modelo de capitalismo (imperialista, financiero, neoliberal) depredador, despiadado, que impone estilos de vida, y mediante el cual se legitima el sentimiento de anular al otro, incluido al no competente, para el éxito del desempeño eficientista; así mismo, la retórica de la inclusión, de una pretendida educación para la igualdad y la justicia social y ambiental, el desdibujamiento de las humanidades en las políticas y currículos educativos, la ambivalencia o el ensimismamiento de la ciencia y la tecnología, la invisibilidad de los saberes ancestrales, del pensamiento intuitivo, consciente y crítico, y de espacios para que los integrantes del acto educativo participen con sus conocimientos, valores, creencias, sensibilidades, sueños y otras especificidades en indagaciones constructivas sobre un pasado $y$ presente contingentes, y sobre un futuro cuya suerte depende de los límites o infinitas concesiones que definamos frente al ideario de progreso que descansa en la racionalidad del mercado y la tecnociencia, para la construcción de realidades sociales, por supuesto inacabadas, en abierta afirmación de humanidad, pluriversidad y vida digna ${ }^{38}$.

Como se ve, no es lo mismo encarar los $38 \quad$ Al respecto es plausible la aseveración de Escobar, A. (2012) en torno al paso que dejan advertir los procesos transitorios del paradigma de la globalización al de la planetarización: "las transiciones anuncian que "la globalización (privilegiadora de la integración económica y cultural y la homogeneización bajo principios universales) no es la última etapa de la modernidad capitalista, sino también el comienzo de mundos nuevos (planetarios)". Ello alienta apuestas emergentes como la que motiva este escrito sobre el papel protagónico que podría tener la educación bajo sanos preceptos para asistir en los compromisos de erigir "un nuevo modelo civilizatorio que trascienda el Universo de la modernidad (Mundo Único) de cara a un verdadero pluriverso de mundos socio-naturales (que abogue por una comunicabilidad entre una multiplicidad de mundos culturales en la base de un entendimiento ecológico y político compartido (Santos, B. 2007)". 
procesos de conocer y enseñar bajo el influjo de una mirada reflexiva, quirúrgica y edificadora, que de manera fría y unilateral: saber por saber, conocer por conocer, el arte de enseñar, o de forma lucrativa. Por el contrario, cuando estos se insertan en la finalidad educativa requieren observaciones, técnicas, procedimientos y estrategias específicas situadas, que la pedagogía y didáctica deberían proveer, despuntando la originalidad ${ }^{39}$. Por estos motivos, una didáctica que descanse en los avances de la neurociencia y los desarrollos de la psicología del aprendizaje y deseche el arjé educativo y pedagógico, no comprometerá jamás los saberes, conocimientos, experiencias educativas y valores humanos en función de la formación de mejores personas ${ }^{40}$. Estará, a contrapelo, a merced de los intereses que mueven las relaciones sociales basadas en una desalmada ideología que respalda la maximización de la ganancia a costa de la

39 Las enseñanzas situadas tienen que ver también con el modo en que influyen en estos actos las epistemologías y teorías sobre el dominio del saber (matemático, histórico, en fin) y las teorías específicas de la enseñanza de tal saber, incluidas las del profesor, junto con sus valores y creencias. Nuestra propuesta tiene que ver con la estimación que en esta interacción podría tener la pedagogía comprensivo edificadora, en particular los presupuestos didácticos sensibles, para que tales procesos adicionen en la formación de subjetividad, y en rigor, de la personalidad humana, por ejemplo a la comprensión ética de los sujetos de la relación educativa, y para que el asunto central no sea, como lo pretende la psicología que domina en las prácticas de enseñanza, el sujeto aprendiz y epistémico, sino además el sujeto persona, y cómo aquel puede afinar como mejor ser humano.

$40 \quad$ La didáctica y la pedagogía pierden personalidad cuando en sus procesos empiezan a pesar acciones, principios y objetos que no son de su exclusivo resorte, lo que puede desembocar en una suerte de colonización epistémica. Ello ocurre por ejemplo cuando en el lugar de la pedagogía se traslapa a la didáctica, y cuando en el espacio de esta última se impone la técnica, el aprendizaje, el saber y el activismo desplazando a otro lugar a la enseñanza y la formación. Una cuestión es que una perspectiva, sea didáctica o pedagógica sirva los propósitos originales de estos campos que atienden la educación, y otra es que se le entronice de tal forma que aparezca como vocera de aquellas. Las perspectivas constructivista, crítica, social o la misma comprensión sentida no son ni deberían ser asumidas como la pedagogía, ni sus brazos operativos como la didáctica. Ni la didáctica es la voz de la pedagogía, ni las orientaciones técnicas o metodológicas son la didáctica. pauperización social y la degradación planetaria y cósmica.

Otra cuestión es la necesidad de que desde la didáctica y la pedagogía se emprendan acercamientos teóricos y metodológicos para percibir en los procesos referidos el sentido edificante de la acción educativa. Por ejemplo, que los dispositivos y estratagemas que se implementen para intervenir en la construcción, apropiación, generación, aplicación y uso de conceptos, conocimientos, saberes y valores, y/o en torno a la reconstrucción de estos, se humedezcan de humanidad. Así, es deseable, por una parte, que la construcción, aplicación y evaluación de cada artefacto para la enseñanza comprometa el movimiento de desempeños tanto cognoscitivos, como operativos y condescendientes. De esta manera, para que un estudiante, de acuerdo con su nivel, se apropie de un concepto u objeto temático, habrá de avanzar, con sus especificidades, dinámicas cada vez más exigentes no solo de tipo cognitivo y metacognitivo, sino también socioafectivo, vivencial y experiencial en torno a la manera como este puede mejorar o alterar su vida, la vida humana y de los ecosistemas. Es claro que un método, estrategia o constructo para enseñar y/o aprender se construye y opera a partir de un educador y/o de un educando, de suerte que quien enseñe estaría en el deber ético de educar con lo que enseña (saber enseñar, enseñar educando), y quien aprende, al menos en la escuela, aprendería a apropiar (subjetivar) saberes y conocimientos con una perspectiva mínima sobre el uso u objetivación edificadora que él y la sociedad darían al objeto de aprendizaje, estando así en el terreno del $\mathrm{ACE}$, que se retoma más adelante.

El acto de educar, como se ha expresado, está en correspondencia con los procesos de conocer y de enseñar. En la institución escolar cabe no solo que quien enseñe sepa hacerlo, sino que involucre en esta actividad insumos propicios para formar mejores seres, y de 
esa manera intentar dominar el arte de saber enseñar educando, para lo cual es primordial el conocimiento de la extensión del concepto educación desde su raíz, y de aquellos de corte teórico, técnico y práxico que dispensa la pedagogía y la didáctica en torno a los procesos de conocer, enseñar, educar y demás.

Enseñar y educar son actos complementarios, interrelacionados: quien enseña educando sabe enaltecer el valor de este acto, creando ambientes para que los aprendizajes escolares devengan experiencias de empoderamiento como persona con gobierno propio y responsabilidad ética, conviviente, solidaria, creativa, crítica, hacedora, innovadora, interesada en sí misma, en el otro y en lo otro (lo humano y lo no humano) que teje su acontecer y la vida. Análogamente, quien educa enseña con el ejemplo de alojamiento del otro, en razón de hacer mejor posibles los aprendizajes comprensivos con la pretensión de que el sujeto educable, acogido en su especificidad, use sus dominios para el crecimiento de sí mismo y con actitud ótrica, de dignificación del otro y lo otro que atañe al ser humano.

Es necesario, aparte de lo señalado sobre el binomio enseñar- educar, un cambio en la cultura de enseñar, una nueva filosofía de la educación, que acentúe en las preferencias y los papeles de los agentes de la enseñanza, que sitúe al profesor en un escenario distinto y lo coloque en una "situación ética" en la que el alumno/a deje de ser objeto de "conocimiento y de control" para convertirse en interlocutor necesario en su proceso de construcción personal (Ortega, 2018). Que blinde la tarea de enseñar de los potenciales ético-morales que la misma entraña. El docente que educa parte, consciente y hermenéuticamente, del reconocimiento de las distintividades de sujeto y contexto; de los compromisos de la educación, la pedagogía y la didáctica con la función de educar, y se reconoce como tal y a sí mismo en la experiencia ótrica de la cual se nutre su mismidad.
Lo expresado hasta aquí se puede aplicar al ejercicio de determinar propiedades generales del saber didáctico que los docentes poseen o deberían adquirir, revestir, enriquecer y modificar para situar su práctica de enseñanza. Obra esta para la cual serían útiles aportes teóricos, conceptuales y metodológicos, entre otros, ahí los comprensivo edificadores, para una didáctica, en lo mejor posible, coherente, que funja como metavalor que logra articular sus elementos o saberes y prácticas en función de aportar en la formación de mejores seres, y por consiguiente una didáctica consecuente, a nivel discursivo y operativo, con el significado profundo del espectro pedagógico y educativo.

\subsection{El saber didáctico de los docentes}

En este espacio se pone de presente algunas orientaciones, sobre todo en cuanto a saber didáctico, que le permitirían al docente ampliar conocmeintos y reflexionar sobre la enseñanza, la didáctica y su práctica, para dirigir enseñanzas que eduquen y exigir mejores condiciones para desarrollar estas. Nuestra reflexión escapa a toda intención de idealización del docente, que ponga su acento en el deber ser soslayando al individuo humano, es decir, no se trata de reproducir la imposición de preceptos a la que se somete habitualmente al docente y su práctica, sino de brindar posibilidades para potenciar su consciencia crítica, creativa y actuante para desarrollar, dentro de sus posibilidades, tales enseñanzas.

Desde la perspectiva CE de la pedagogía y la didáctica, cuyos pilares se mencionan a lo largo de esta comunicación, reafirmados en el apartado siguiente, el saber didáctico de los profesores ha de estar marcado por las realidades escolares, que incluye las excepcionalidades de los sujetos, inclusive su naturaleza o habitancia digital; y por las relaciones de otredad, de apertura hacia el otro, el sujeto educando necesitado de humanización, de reciedumbre en los ámbitos configurantes de su personalidad: aca- 
démica, ética, física, política, social, cultural/ digital, ambiental, entre otras (Arboleda, 1995, 2000, 2002, 2004, 2005, 2008 a 2008b, 2011 a, 2011b, 2011c). Un saber que apunte a la construcción de sentido crítico y sentido de mundo comúno, a partir de la naturaleza misma de las dimensiones de los actores de la relación de aprendizaje; el primero dado por actuaciones permanentes en correspondencia con un pensamiento propio, autoconsciente, y el segundo, por la experiencia de uso ético y no insolidario de sus conocimientos y saberes.

El maestro confrontará sus conocimientos didácticos, que han de incluir los fundamentos epistemológicos de las ciencias, en tanto lea de manera consciente, crítica y no consumista su quehacer, su entorno y los fenómenos del reino del mercado sobre la vida, las formas de apropiación y uso del conocimiento disciplinar, las carencias de sus alumnos en materia no solo de socialización (propósito limitado que se impone en las conceptualizaciones pedagógicas y didácticas), sino de humanización, que incluye éste, así como el sistema educativo nacional y las tendencias de la educación y la didáctica; se lea a sí mismo como humano, como enseñante y como educador. Es deseable que este movimiento oscile en doble vía de la práctica a la teoría, y ponga en evidencia el carácter no uniforme del saber didáctico, disciplinar y de los aprendizajes.

Tal saber ha de correr paralelas con la acción didáctica, dinamizada por lo que hemos denominado la pausa didáctica (Arboleda 2011b), un dispositivo que podría ser clave en la praxis del maestro, instalado en una lógica emergente e innovadora, distinta a la vanidosa lógica hegemónica, donde la observación, la reflexión ética, antropológica, actuante y sensible sobre la acción didáctica es permanente, desde antes, durante y luego de la intervención. Dicha pausa permite al docente cuestionar la lógica e intereses del sistema escolar, sopesándolos con las realidades socio culturales, incluidas las de los estudiantes, y en general con los principios fundantes de la pedagogía y la didáctica, en particular con la función de educar adscriptible a estas; anima la indagación crítica sobre el significado humanizante o despersonalizador del acto educativo y de la misma didáctica cuando se ensimisman en sus actuaciones buscando, valga reiterar, más resultados técnicos que de tipo humanitario. Pero también es imprescindible para determinar y crear estrategias para mejorar, de acuerdo a sus propios ritmos, intereses y contingencias, sus desempeños y saberes, y los de sus estudiantes, en función de la noble finalidad educativa. Lo que hace de esta metodología un constructo introspectivo, reflexivo y crítico - actuante.

Es deseable igualmente que el saber didáctico del docente no solo le sirva en los procesos de enseñanza sino tambien en su función como educador. Tal saber ha de ser CE, con lo cual se significa aquí dos aspectos: uno, que el docente logre comprender el saber didáctico, seleccionando aquellos desarrollos del campo que realmente sustancien los eventos peculiares del aprendizaje situado, que pasa por reconocer al sujeto y acompañarle de manera estratégica, propositiva y con actitud hospitalaria en su aprendizaje y formación, de acuerdo, quepa insistir, con las características específicas del entorno en que éste vive, y de sí mismo, por ejemplo sus conocimientos previos y fortalezas cognitivo afectivas, metacognitivas, intereses, motivaciones, actitudes y disposiciones, ritmos y estilos de aprendizaje, entre otros, generando oportunidades y capacidades para elevar, en lo posible, estos; por otra parte, el saber didáctico del docente es CE si éste logra aplicarlo desde el recibimiento, acción esta que no solo requiere el intento de reconocimiento de la situación real del estudiante en materia contextual y de su actividad interna, tanto como la selección de los saberes didácticos y pedagógicos que armonizan con una enseñanza situada, sino en la 
disposición, actitud y saber pedagógico para introyectarlo en su propia existencia y habitar con él en la otredad que humaniza.

Sin lugar a dudas los aprendizajes a los cuales se hace referencia deben pasar por el tamiz del acogimiento como deber ético, de modo que la alteridad envuelva la praxis de enseñanza; las comprensiones del docente han de pasar por la viviencia de la alteridad. La disposición ótrica del docente está en la base del saber didáctico CE que reclama el evento de enseñar educando. No hay saber didáctico CE si el ámbito de la enseñanza no pasa de ser un asunto técnico (de influencia cognoscitiva), a un asunto de humanidad, si se prefiere de vida, manifestable al asumir con entereza la responsabilidad ética de educar en un marco de reconocimiento de sí mismo y del contexto, y de relaciones de otredad. Nadie comprende si no ha apropiado de manera distensionada y consciente, crítica y analítica un objeto de conocimiento, y vive experiencias de aplicación, vivienciación, indagación y uso del mismo; por efecto, la CE de la praxis de enseñanza pasa por el autoconocimiento, el análisis y meditación sobre sí mismo, y se pone de presente en la experiencia de intimidad que el docente que educa vive con el aprendiz educando: la experiencia del docente de saberse educador, y la experiencia del discente de vivir la acogida ótrica. Difícilmente se puede amar a otro sin amarse a sí mismo, ser amigo de otro sin autoempatía, o pretender comprender a otro sin consciencia de sí mismo.

Un saber didáctico de esta condición hace necesaria una formación pedagógica desde la lógica del universo de la vida (ecosistémica), basada en supuestos de alteridad, de sensibilidad socio ambiental, de afirmación de una episteme de la vida y de la temporalidad de las situaciones, hechos y acontecimientos que tejen esta, y no desde la lógica que prima en la escuela, que coacciona, funcional a la racionalidad temporal de un mercado despersonalizante, que ha hecho de la nuestra y para decirlo con Bauman (2000), "una sociedad líquida", y si se me permite, una escuela y una vida líquidas en tanto discurren fieles a los poderes hegemónicos que para su reafirmación hacen más precaria la existencia. Tal saber supone, asimismo, una formación pedagógica propositiva, útil a la determinación de desaprender para construir un saber didáctico en el que lo imperativo no sea aprender contenidos para enseñar sino seleccionar y construir aquellos que acompañen a los sujetos del acto educativo en el camino de aprender a vivir de manera benigna; un saber ubicado, crítico, sentipensante y gestor, es decir, CE. Que afine en estos la aptitud y actitud de leer semánticamente el aula y su propia acción didáctica y pedagógica, haciendo lo propio para actuar en consecuencia.

El saber didáctico CE ubicado en las relaciones pedagógicas se pone de manifiesto, entre otros hechos, cuando el educando se sabe recibido, léase personalizado por el docente, apreciado, reconocido, escuchado, estimado, respetado, considerado en su vulnerabilidad, en sus ideas, inquietudes, acompañado en sus propias búsquedas, carencias y soledades familiares y sociales; si distingue en el docente un agente que lo emociona ante el saber, un cómplice en su aventura de aprender de acuerdo a su propia diferencia específica y de vivir la educación como bien social, que le enseña a interpretar la realidad en su pluralidad, ahí la social, a fundamentar el mundo externo y su realidad personal, a desidentificarse ${ }^{41}$, que le aporta en su despliegue hacia la mayoría de edad intelectual y afectiva, su autonomía responsable y su postura de connivencia ótrica, investigativa y crítico ejecutora, que pacta con él los criterios de evaluación como acto sentiente del aprendi-

$41 \quad$ En el significado que le confiere Cuesta y otros (2005b), de "pensar contra uno mismo", de poner en cuestión las raíces de lo dado comprendiendo su realidad históricoconstruida y huyendo de cualquier esencialismo ahistórico. Desidentificar equivale a problematizar, a pensar contra las verdades asentadas, contra las raíces de lo establecido. 
zaje y la formación, en fin que lo acompaña y orienta hasta donde sea posible en su nuevo nacimiento como educando otro, producto de lo que hemos denominado el parto edificador o pacto pedagógico formativo (PPF), metáfora CE que se retoma en el siguiente segmento.

El saber didáctico y las enseñanzas que educan por y para la vida se distinguirán de las didácticas y enseñanzas que insuflan los aprendizajes asimilables a las dinámicas del orden social y el modelo productivo (destructivo) que suponen una formación de capital humano más que de personas. El rasgo diferencial lo marcaría la posibilidad de que aquellas didácticas dirijan sus acciones hacia (si se me permite) la globalización de la tarea humanizante de modo que las relaciones educativas y entre los seres ecosistémicos se desarrollen con sentido glocal, de respeto a su dignidad concreta, como seres merecedores del pluriverso. Punto de vista que está en la base de las consideraciones de la PCE, indispensables para definir la propuesta de una didáctica comprensivo edificadora (DCE).

Con lo expuesto hasta ahora y provistos de perspectivas didácticas y pedagógicas que atienden la educación crítica, acontecimental, experiencial, mesoaxiológica, radical inclusiva, ótrica y comprensiva, explicitaremos ahora algunos aspectos relevantes del contenido y forma de una didáctica comprensivo edificadoras. Ello en el marco de nuestro reclamo de sensibilizar la didáctica, para que sus conocimientos teóricos y prácticos se construyan, reconstruyan y usen con conciencia ético actuante, pues la humanización de las prácticas educativas precisa una didáctica sentiente, ubicada en el lugar histórico, ambiental y cultural que habitan los intervinientes en la relación educativa; que enfrente la institucionalidad (política, educativa y demás) que ha erradicado, excluido desde la raiz el sentido más íntimo de la educación y sus saberes asociados, por crear demandas que no corresponden a la finalidad educativa ${ }^{42}$ ni a las 42 Con Touriñán (2019), la finalidad de la educación, necesidades más hondas del ser; una didáctica edificadora que se sume a la vida atendiendo estos pasivos o radicales, promoviendo en sus (re)formulaciones relaciones distintas con nuestro averiado planeta, es decir otros modos de relación de las personas con consigo mismas, con el otro y con lo otro, en lugar de ir en la vía de la construcción deóntica (de lo debido, de lo necesario, del deber ser) en la que, por el contrario, se ha mantenido, conducida por una ética antropocéntrica copiloteada por un antropocentrismo, excluyente del otro y lo otro digital, vírico y civilizatorio, vivo y no vivo, telúrico y pluriverso que nos constituye y hemos de humanizar y cuidar.

\section{UNA DIDÁCTICA COMPRENSIVO EDIFICADORA}

En este aparte de la exposición se propone una perspectiva didáctica por y para la vida humana y planetaria, que sirva de referente a las prácticas y acercamientos indagativos e investigativos en torno a la enseñanza, el aprendizaje y la formación, de suerte que estos actos se desarrollen de frente a la construcción de escenarios para afirmar al hombre, la naturaleza y en general al pluriverso: la didáctica comprensivo edificadora (DCE) $)^{43}$.

es, por definición, que el educando adquiera conocimientos, actitudes y destrezas-habilidades-hábitos que lo capacitan, desde cada actividad común interna (pensar, sentir afectivamente-tener sentimientos, querer, elegir-hacer (operar), decidir-actuar (proyectar) y crear: construir simbolizando) y externa (juego, trabajo, estudio, intervención, indagación y relación), para decidir y realizar sus proyectos, dando respuesta de acuerdo con las oportunidades a las exigencias que se plantean en cada situación.

43 La perspectiva comprensiva edificadora (PCE) destaca las connotaciones pluriversales de la vida. Asume ésta como el estado en que tiene lugar la evolución humana y planetaria, el decurso interconectado de mundos, universos, seres vivos y no vivos que tejen el pluriverso, a la luz los derechos del hombre, de la tierra y el planeta; y también, de acuerdo con Escobar (2012), como "el conjunto interminable de formas y entidades que componen el pluriverso -desde lo biofísico a lo humano y lo sobrenatural-y los procesos por los que vienen a ser", lo que va más allá de una preocupación por la 'naturaleza'. Como constructo emergente aboga por construir 'mundos y conocimientos de otro modo', es decir, mundos y saberes establecidos sobre la base de los diferentes compromisos ontológicos, configuraciones epistémicas y prácticas del ser, saber y hacer. 
Cuando desarrollamos nuestro potencial de comprensión edificadora (de usar las comprensiones con sentido de vida, de existencia y de mundo humano y común, lo que precisa la posibilidad de alterar desde el lenguaje comprensivo nuestra historia, la historia y el mundo), que propicia el hecho de ser seres lingüísticos, estamos reivindicando no solo el atributo práxico de la comprensión y del lenguaje sino fortaleciendo esta dimensión, también nuestra pluridimensionalidad (nuestro "micro" espacio común: el conjunto de dimensiones que nos conforman y son interdependientes, tales como la física, psíquica, ambiental, social, política, histórica, entre otras), y en consecuencia ganando otredad, humanidad. Lo cual corrobora, según mencionamos en el pie de página previo, la capacidad hacedora y formativa del lenguaje y la comprensión.

La PCE ofrece reflexiones y mecanismos para una enseñanza focalizada, si se prefiere ótrica, así como para el fortalecimiento de aprendizajes comprensivo edificadores (ACE), en los términos que se ponen de presente a lo largo del capítulo. Una didáctica de sustrato ético y antropológico, dirigida a revalorizar y viralizar la vida en las enseñanzas y los aprendizajes, que medie por la comprensión ética como canal de ascenso humano.

La comprensión ética (y aún la comprensión),

La CE supone una ontología no metafísica de la comprensión edificadora (CE) como dispositivo que agencia nuestra consciencia de mundo, de los fenómenos, procesos, situaciones $y$ en general de los objetos reales, ideales e imaginarios que lo constituyen; una comprensión, una consciencia actuante que obra en nuestra propia humanización, que carga de sentido nuestro sí mismo, un sí mismo ótricamente edificante de sí mismo, del otro y de lo otro, permitiéndonos saber ser comprensiva, humanamente otros, seres más humanos protagonistas reivindicadores de mundo común. De esta manera se asume el lenguaje y la comprensión como potenciales activos, generativos si se prefiere, más allá de las bondades expresivas del lenguaje e interpretativas de la comprensión. Se trata del lenguaje como dimensión concreta, constitutiva y formativa del ser humano. Constitutiva porque ontológicamente el individuo humano es lenguaje, somos seres en el lenguaje, como seres en el mundo. El lenguaje hace parte de nuestra dimensión cultural y es condición para la evolución de las demás dimensiones del ser humano, y para nuestra formación como seres humanos. como uno de los postulados de la perspectiva en referencia y concepto básico en nuestra propuesta de ACE constituye un faltante radical tanto en la didáctica como en la enseñanza y en el aprendizaje ${ }^{44}$. Para que una comprensión revista carácter ético precisa tintar de humanidad el saber hacer (que implica el saber ser) de los comprendedores, sea el didacta, el metodólogo, el directivo, el enseñante o el educando; de lo contrario estaremos ante una comprensión técnica, importante sí en la cotidianiidad y en los procesos de aprendizaje, más insuficiente para los procesos sustanciales que demanda el acto de educar y la educación.

El tema de la comprensión aún traba el acaecer didáctico, las enseñanzas y los aprendizajes -en tanto gravita en estos el asunto cognitivo, relegando e incluso ignorando que el fenómeno experiencial y vivencial es al final el que asegura la construcción de sentidos y significados que dan figura a toda comprensión, pero más aún, el de la comprensión ética. Como hemos señalado, para comprender no es suficiente conocer y entender: sin experiencia a partir del conocimiento subjetivado, apropiado, no hay comprensión; y en el caso de la comprensión ética el sujeto ha de vivir junto con su comprensión cognitiva o crítica, una experiencia objetivizantemente ótrica, como otro responsable del otro y lo otro común. No se agudizan los grados de comprensión, que no ocurren en un contininum, si no se procesa adecuadamente la información para convertirla en conocimiento, si no se contempla, indaga, reflexiona, analiza, genera, discute y aplica el objeto de acercamiento en contextos diversos ${ }^{45}$; la comprensión $44 \quad$ Las enseñanzas que educan favorecen generalmente los ACE, en tanto acompañan a los educandos en la realización de desempeños sentidos, y no prediseñados, de ribete cognitivo, afectivo, generativo y operativo; en tanto proyectan luces para que el educando forme comprensiones y las use para su construcción personal, para la evolución humana y de la vida, imprimiéndole al proceso un carácter ético, de comprensión ética. Sin enseñanzas que eduquen no hay posibilidad de generar comprensiones éticas y por tanto ACE.

$45 \quad$ La apropiación crítica de información (que representa un nivel o grado importante de comprensión) es más 
se realza cuando el comprendedor viviencia el conocimiento, al objetivarlo en escenarios reales, ideales o imaginarios que conforman su experiencia de mundo, su mundo de vida, sobre todo en sí mismo (reobjetivación subjetiva) y/o en su entorno (lo que pone de manifiesto el concurso de procesos que no son exclusivamente cognitivos). La comprensión ética es, como toda comprensión, analítica, interpretativa, crítica, generativa y vivencial, pero además es responsable, es decir al usar sus comprensiones el sujeto deja que aflore el otro que llevamos por dentro, y no ha de atentar contra sí mismo, el otro y lo otro incluido el entorno humano y no humano. Si gana ribetes de comprensión ético estética, la responsabilidad del ser aparcaría también en el despliegue de imaginación creadora que precisa vivir de modo más humano.

Insistimos aquí en la necesidad de vencer el hermetismo de los saberes didácticos y culturales, aún los especializados, renuentes a incorporar abiertamente los principios originarios y más íntimos de la edificación. La didáctica propiamente no puede ceñir su acción al estudio del sujeto epistémico, a la formulación y aprobación de tecnicismos e instrumentación, ni tampoco orientar su producción hacia una enseñanza y aprendizajes al margen de la función de educar, que deriva la responsabilidad de acompañamiento entrañable al sujeto educable en su alteridad, la diferencia específica y contingencial de éste y del entorno socio e histórico cultural; es menester que proyecte luces para que desde estos actos se eduque, se humanicen tanto la transposición o reducción de saberes culturales a saberes enseñados o formativos, y la influencia para que estos devengan saberes apropiados por el aprendiz, como los procesos de generación, aplicación y uso de estos, de valores y actitudes, contribuyendo de este modo al alcance de los propósitos educativos y sociales que le conciernen a su actividad para la for-

urgente toda vez que la tecnología ha logrado avanzar haciendo de la vida un mar de información del cual bebe insaciablemente, impactando no siempre positivamente en esta. mación de mejores personas; lo que impone a las transposiciones didácticas "sensibilizar" sus procesos.

Es preciso "vitalizar" la didáctica para que contribuya genuinamente en la finalidad de hacer de la otredad, la emancipación y la humanización de la vida y la existencia pulsiones, conductas cotidianas en el acto educativo y formativo concreto. Hace falta más reflexión que tecnicismo didáctico, para que emerja una didáctica situada; que se ocupe más de sí misma, de repensar su sentido de vida, su sentido social, común, su sentido humano y epistémico. En proceso de situación, de relocalización la teoría y el tecnicismo didáctico develarán prácticas consecuentes.

La educación, la enseñanza, y la pedagogía y la didáctica que las abordan tienen funciones sustancialmente éticas, y en esa dirección los pedagogos, las ciencias y actores de y por la educación han de labrar las condiciones para su reorientación, pues derivan, por fuera del cause primigenio de servir propósitos humanizantes, en las aguas turbias de los órdenes y lógicas que hacen de las mismas conductos para reproducir sujetos competentes, hábiles, sin potenciales compasivos, crítico y comprensivo edificadores de vida humana y planetaria. Una forma de desobediencia civil para ser reside en enseñar educando, educar para hacer lo correcto moralmente, es decir para romper la normalidad agobiante, pues en virtud a la interconexión que viven los seres vivos y no vivos, que nos ata a lo otro y al otro, este comportamiento incidiría en el complejo que conformamos; y lo contrario lo empeoraría, apuntalando la mismidad y la normalidad deshumanizantes. Ello no es imposible. Adeudamos generar pedagogías umbilicales, es decir aquellas, como las emergentes ${ }^{46}$, que

$46 \quad$ Frente a la desorientación inexorable de la educación, la pedagogía y los saberes educativos, ahí la didáctica, que se torna más evidente con los fenómenos cada vez más dramáticos de racismo, individualismo, desigualdad, injusticia y deterioro humano y planetario, surgen en este siglo perspectivas que abogan por la reivindicación de los principios originales y más sentidos de la educación, la pedagogía y la formación. Es el caso de los constructos que sustentan nuestra reflexión propositiva y con los cuales se 
promuevan el nacimiento escolar de seres con consciencia comprensiva y actuante sobre el lugar que como humanos tienen en el pluriverso interconectado del cual hacen parte ${ }^{47}$.

Bajo esta ausencia, la pedagogía comprensivo edificadora (PCE) en la cual tiene lugar la DCE, pretende ser un referente emergente para la formación de profesores y en general para la educación, los actos en que esta se expresa y los saberes que la abordan. Forma a su vez parte del pensamiento disidente o espacio onto-epistémico resistente a la que podemos denominar ego-episteme planetaria (el reinado de una episteme como la moderna que cada vez favorece el ego, el sentido no común, la privatización de la vida, de la naturaleza y del mismo hombre por obra de la duo-deidad saber-poder financiero que asimila a sus intereses y enunciados a los estados, a la sociedad y al planeta), bajo la cual acontece en la educación, en la ciencia y en la existencia el divorcio saber-vida, como derivación de la escisión de la malla o relación inextricable, que oxigena la existencia, entre seres orgánicos e inertes.

En el contexto de la didáctica esta orientación brilla en latitudes donde este campo presenta algunas carencias en los terrenos teórico y práxico, particularmente alentaría la generación de un nuevo ethos, otra forma de acción y relación con la enseñanza y los aprendizajes, que promueva la sintonía en la vida individual de la responsabilidad ótrica, de educar, de enseñar acogiendo, de participar de manera activa en la búsqueda de ámbitos de actuación más

dialoga aquí: fundamentalmente las perspectivas mesoaxiológica (PM), de la alteridad (PA), radical inclusiva $8 P R I)$ y comprensivo edificadora (PCE). Su umbilicalidad está determinada por el lazo que une a la educación y los saberes educativos con la vida, con el sentido de comun-idad, de otredad humana y cósmica, es decir de presencia inexcusable del otro y de lo otro en el sí mismo de cada ser humano.

47 Esos nuevos seres son, como se expondrá, los sujetos auténticos de la relación pedagógica: el educador y el educando. Estos no existen por fuera de la relación pedagógica (por fuera de esta solo habitan el profesor y el estudiante), son sujetos emergentes, concebidos y gestados en la acción pedagógica, en el marco de acogimientos, de relaciones de alteridad ética. humanos para sí mismo, para el otro y lo otro. Es claro que la ética debe discurrir en toda la geografía de la educación, incluidos el saber pedagógico, la enseñanza, el aprendizaje, el currículo, la evaluación y demás saberes que la abordan; sin embargo, la ética del acogimiento no ha sido encarada cabalmente en los desarrollos de la ciencia de la enseñanza ni en las prácticas educativas, y cuando se la aborda es solo en un marco reflexivo no actuante y por tanto idealista, ni innovador ni generativo y menos edificador. La enseñanza transita aún huérfana de la ética, y por tanto no se afronta como praxis, como quehacer compasivo, más que técnico y tecnocrático. De acuerdo con Ortega, P. (2020), hacer de la acogida y la hospitalidad una práctica en la educación supone el abandono de una concepción idealista del ser humano y de una moral que ha hecho de la "obligación y el deber" su objetivo prioritario.

Frente a los pasivos que permanentemente se advierten en la pedagogía, están aquellos que posee la didáctica en torno a la función de educar. Reiteremos. La didáctica no solo tiene que ver con contenidos, con los medios y procesos de enseñanza, aprendizaje y formación, sino además con la función de educar. Es recurrente la asociación de este complejo con el acto de enseñar, como saber relacionado con la intervención en los procesos de apropiación y movilidad del conocimiento, como segmento de la pedagogía inherente a los métodos y técnicas de estudio, y a los procesos y fenómenos que intervineen en las prácticas de enseñanza. No obstante y sin negar que ésta aporta dispositivos y reflexiones en y sobre tales situaciones, así como observaciones sobre los procesos de enseñar, y sobre la calidad ${ }^{48}$, mejor sobre el rigor

$48 \quad$ Calidad educativa es un concepto acuñado en el ámbito de la gestión de mercados, inherente a la pertinencia, eficiencia y rendimiento del proceso educativo de norte a los lineamientos y parámetros que aseguran el éxito empresarial. Para ello son inevitables los "principios" de homogeneidad de pensamiento y de desarrollo de competencias para saber, ser y hacer que ha de asegurar la gestión educativa y pedagógica, de acuerdo a las metas educativas y extraeducativas. El "éxito" está determinado por el grado de competencia de las instituciones y sus miembros. 
de la intervención que en estos realizan agentes culturales tales como los padres de familia y los hijos, los evangelizadores, los comunicadores, el personal médico y los pacientes, los profesores y los mismos estudiantes; hay hechos, encima de los mencionados, que no están presentes siempre en las indagaciones didácticas.

Así, uno de los asuntos que hace o haría de esta ciencia un campo prominente en la educación y la formación, es que sus contribuciones sirvan finalmente para que el educador pueda avanzar idónea y éticamente su acción de acoger al educando de cara a que este construya no solo conocimientos y saberes, también apropie no saberes ${ }^{49}$, actitudes y valores, y en el mismo proceso constructivo vivencial procedimientos para el uso contextualizado y generoso de estos, para el bien propio, del otro y de lo otro. Nuestra naturaleza relacional supone que todos los seres interconectados son necesitados, son carentes, y en consecuencia el sujeto humano tiene la responsabilidad de acoger con fuerza ética al necesitado, al otro y a lo otro, no sin cuidar de sí mismo, siendo en esta acción corporizadora de la otredad que logra afirmar y cultivar su propia subjetividad (ótrica). Es esta la gran misión y deuda histórica de la pedagogía y de los saberes y practicas educativos, al no poder darle forma y contenido al ejercico de sus funciones asociadas a formar en la capacidad de ser y existir con consciencia interdependiente, orgánica y actuante, es decir que afirma en la vida su naturaleza interconectada (consigo mismo, con lo otro y lo otro), que piensa, imagina, reflexiona, delibera, decide, participa y siente el latido relacional acompasándolo en sus

La calidad educativa se entiende aquí como el proceso orientado a desarrollar con rigor los principios fundantes de la educación y de la democracia, que permitan a los miembros de la relación educativa fortalecer y desarrollar potenciales para ser mejores seres humanos que cuidan de sí mismos, del otro y de lo otro que teje la existencia.

$49 \quad$ Nahuelquir y otros (2011) tratan de demostrar cómo lugares concebidos como vacíos, ausencias, silencios ó desconocimiento (no saberes) pueden, en determinados contextos, devenir en lugares de transmisión, de experiencias de constitución de subjetividad y de visibilización de imposiciones hegemónicas. actos.

La didáctica se reafirmaría en la fuerza edificadora de los conocimientos y procedimientos que los interventores ponen de presente en su misión: si estos poseen, además de dominio del arte y la ciencia didácticos, de sensibilidad ótrica, podrían propiciar un uso de potenciales técnicos y humanizantes empático con la naturaleza y en general con los ecosistemas, y por efecto, una apropiación semántica perdurable ${ }^{50}$.

El verdadero educador genera ambientes de distensión para que los estudiantes se motiven, se interesen, deseen y sepan comprender, deliberen en torno a conceptos, situaciones y fenómenos, imaginen y se evalúen de acuerdo con sus propias temporalidades, estilos y motivaciones; involucre a estos en el diseño de actividades, en particular de talleres ${ }^{51}$ que incluyan procesos básicos de comprensión y uso edificador de conocimientos (en los cuales se vivan experiencias de vinculación de los temas o proyectos de aula con la historia personal y social, con algunas situaciones, fenómenos y hechos del presente y el pasado, relacionados con la ciencia, el contexto social, económico, ambiental, cultural o político, construyendo sentido de vida a partir de lo que se comprende) y sean desarrollados de manera individual o mejor en equipos heterogéneos e incluyentes (conformados por estudiantes con más ventajas unos que otros, bien en materia cognitiva, actitudinal

$50 \quad$ Frente al panorama de aprendizajes frágiles en los cuales los conocimientos apenas asoman, desapareciendo rápidamente del esquema mental del sujeto, urge reconocer que la perennidad de un conocimiento en la estructura mental de un individuo pasa por las actividades en las que éste logre vivenciar aquel, lo cual amplifica la construcción de significados y sentidos, afianzando la comprensión (Arboleda, 2013). Si lo usa con finalidad benévola, con actitud ética, para el bien individual, social y de la vida, se resignifica mucho más el objeto de comprensión, se invulnerabiliza el nuevo conocimiento y se consolida la comprensión ética, ótrica si se estima. Ello obedece en gran parte a que la experiencia vivencial, y más si esta es entrañable, reverberaría en la psique, marcaría indeleblemente a la persona.

$51 \quad$ Al respecto hemos propuesto en otros espacios (Arboleda, 2005, 2007, 2011b) dispositivos y metodologías como el Taller Comprensivo edificador, Trabajo en equipo y el Padrinazgo sentipensante (inicialmente denominado padrinazgo cognitivo/afectivo). 
o afectiva) basados en la corresponsabilidad y la ayuda mutua, siendo estos y su exposición oral y escrita el gran recurso para la evaluación, asumida esta como un proceso democrático y no despótico, dirigido a fortalecer los aprendizajes por comprensión, el sentimiento moral y la actitud académica, investigativa, ética, ciudadana. Es ese un modo de acoger al educando, de aportarle para su mayoría de edad, su saber ser otro, promoviendo en él sentido de otredad, sensibilidad social, solidaridad, integración, participación en el cuidado de sí mismo, del otro y de lo otro, así como un encuentro con el saber más placentero que agobiante; una manera de internalizarlo en su propio yo como educador, y también un modo de residir, de situarse en la propia historia de éste.

En este asunto tal vez sean pertinentes, asimismo, las contribuciones de la pedagogía por proyectos de vida (PPV), enfoque sobre el cual emerge la PCE, convirtiéndose en un capítulo de esta última. Sus reflexiones y metodologías sirven la finalidad de educar por proyectos de vida, es decir que la acogida del sujeto educable sea radical y severa e inicie con el intento de reconocimiento e inyección de cada uno de los matices de la personalidad de estos. Aboga por el fortalecimiento, a través de la educación, de las dimensiones que constituyen al individuo para vivir como mejor persona ${ }^{52}$, por lo que la otredad didáctica y educativa se expresa en el apoyo a la construcción de proyectos de vida

52 LaPPVexpone el presupuesto según el cual quien no construye proyectos (actitudes) de vida enfila proyectos (actitudes) de muerte. La globalización es un proyecto de muerte que impacta al ser humano y al ecosistémica (la interconexión entre los mundos que integran el Gran Ecosistema, incluido el mundo humano), y la educación se deshace en tal proyecto al utilizar al sujeto educable como acicate para reproducir la racionalidad egocéntrica. Hacer de la vida una cotidianidad del aprendizaje es de hecho una manera de proyectarla. Un estudiante y todo individuo puede proceder de mejor modo en su acontecer si despliega planes de vida que eleven las facetas que configuran su estructura radical como individuo humano: la académica, social, ética, laboral y demás. Este proceso les abriría las puertas para la indagación sobre el sentido de la vida, y entregarse a la tarea de ser artífices en la generación de mejores espacios para la trayectoria humana, de los ecosistemas y la suya propia (Arboleda, 2019b). en los educandos, que les permita generar sentido de vida personal y elegir su modo de vida, intentar ser más dinámicos frente a sus metas, sueños y esperanzas casi siempre truncados ${ }^{53}$. La importancia de educar por proyectos de vida radica en que la vida humana se afianza en los propósitos de vida. No es lo mismo vivir sin propósito que con finalidad. La educación tiene valor si educa en la responsabilidad de vivir con intencionalidades, y muestra alternativas al educado para que formule propósitos de vida en diversas esferas de la realidad personal, social, cultural y planetaria, enseñándole a gestionarlos, lo cual es posible si tales propósitos se expresan en planes y proyectos de existencia en espacio común. No basta con tener un propósito, hay que saber formularlo y blindarlo, darle forma y contenido a través de proyectos; al margen de estos difícilmente el individuo podrá soñar despierto, será incapaz de atenuar hasta donde sea posible su fragilidad connatural, no podrá salir de la minoría de edad en la que viven los sujetos y las sociedades, designado a padecer los proyectos de muerte que traza (por ellos) el artefacto del modelo de desarrollo que muele la vida humana y telúrica.

La didáctica juega aquí una función única si genera indagaciones e investigaciones que sirvan para robustecer en lo posible procesos que tributen al rumbo de la personalidad humana en cada sujeto, y cómo este puede ser actor protagonista de su propio crecimiento como persona. En este horizonte una didáctica por proyectos de vida (DPP) asumiría en sus objetos de abordaje las dimensiones del sujeto, entre otras ética, física, valórica, ecosistémica, cultural/espiritual, política, así como la esfera psíquica de la cual hacen parte la cognición, la

$53 \quad$ La construcción de proyectos de vida, sean personales o colectivos (grupos, familias, organizaciones y comunidades, entre otros), hace referencia a la formación de consciencia edificante, por la cual se gestionan propósitos, se diseña, implementa y asumen compromisos o planes específicos para el cuidado y desarrollo propio y de la existencia, procediendo como mejores personas, con autonomía, actitud conviviente, protagonistas en la edificación de mundos más humanos para sí mismos y para la sociedad. (Arboleda, p. 14).. 
afectividad, la percepción, la atención, la voluntad, la imaginación, el pensamiento, la inteligencia, entre otras funciones mentales, desde una mirada relacional en la cual tenga conocimiento fiable del cual disponer para la mejora de algunas o cada una de estas, y al desempeño articulado que de las mismas requiere el individuo para conducirse de modo más adecuado en las dinámicas complejas (de incertidumbre, no linealidad, contingencia) de su existencia y entorno presentes, cambiantes.

Una estrategia amigable a estos propósitos sería el fortalecimiento de proyectos de vida personal y comunitario (Arboleda, 2007, 2011, 2019), para lo cual los aprendizajes escolares estarían, en lo factible, en función del crecimiento pluridimensional del educando, y no solo enfocados a las destrezas del competente que pretenden los curricula. Convenga subrayar aquí que la formación de y en las dimensiones complejas de la personalidad (de la estructura radical) del individuo se matiza al atender el impulso de pensamientos múltiples actuantes ${ }^{54}$, si se prefiere comprensivo edificadores, es decir potenciar desde las áreas del currículo diversas modalidades del propio pensamiento, entre otras las fuerzas intuitiva, consciente, reflexiva,

$54 \quad$ En esta perspectiva se asume la expresión pensamientos múltiples como estrategia cognitiva y pedagógica para atender situaciones de orden real, ideal o imaginario, que fuerzan el uso de operaciones, representaciones y decisiones correspondientes a diferentes tipos de pensamiento que se ligan en la acción de pensar de los sujetos que los han desarrollado. Corriendo paralelas con esta demanda la enseñanza y la formación tienen la responsabilidad de observar, reflexionar, diseñar y desarrollar metodologías para la formación e interacción de pensamientos múltiples (crítico, social, histórico, creativo, comprensivo, ético, entre otros), provechosa instancia a la hora de encarar las situaciones cada vez más complejas que provoca la era de la globalización, tanto como el reto de ser constructores de una sociedad y una vida auténticamente humanas. (Arboleda, 2011c). Finalmente, con este concepto también se reafirma la necesidad de que la epistemología, la enseñanza y la didáctica no se encasillen en el sujeto epistémico (en lo que este requiere, puede, quiere o debería saber), sino que avancen hacia la formación que procure hacer en el educando rutinaria la actividad de "pensar, actuar, dialogar,... sobre las "cosas", a partir de lo que sabe (Font, V., 2006) con responsabilidad ecosistémica. El "Taller de pensamientos múltiples" es una de las estrategias didácticas desde la cual contribuye al respecto la PCE-DCE. crítica, analítica, biotecnológica, matemática, lingüística, creativa, innovadora, investigativa, ética, social, histórica, cultural, ecológico/ambiental e inclusive el pensamiento metafórico ${ }^{55}$, que incluyan en el proceso la vivienciación de los mismos. Tal experiencia viviencial aportará réditos al crecimiento de los elementos que configuran al ser personal del educando (Arboleda, 2000, 2002, 2007, 2011b-c), pues la evolución de la pluridimensionalidad del sujeto es proporcional al desarrollo de pensamientos múltiples, y recíprocamente, marcando el crecimiento personal.

Un caso es el estímulo del componente ecológico-ecosistémico del individuo, el cual se podría adelantar tras el reconocimiento crítico acerca de la importancia de éste en el espectro humano y en general en el Ecosistema, el desempeño y actitud personal, ciudadana, empresarial y gubernamental frente a esta responsabilidad, y el empoderamiento personal y colectivo para obrar en correspondencia, con sensibibilidad ambiental y mentalidad propositiva ${ }^{56}$. Todo ello implica las modalidades del pensamiento, que la escuela puede ayudar a movilizar en el marco de proyectos de aula y talleres de emprendimiento ecosistémico, algunos de los cuales hemos presentado en Arboleda (2000, 2002, 2004, 2007, 2010, 2011). El Taller Comprensivo edificador, recurso de la metodología Aprendizaje por problemas edificadores (APE), es ilustrativo de esta intervención escolar en la mejora de esta dimensión humana (Arboleda, 2019). Se parte, estrategicamente, de identificar de modo individual $55 \quad$ Forma de pesamiento de gran impacto en la didáctica de la matemática, que, para decirlo con Font (2006), consiste en la interpretación de un campo de experiencias en términos de otro ya conocido (...), el mecanismo cognitivo que permite que lo abstracto se comprenda en términos de lo concreto.

56 Ante todo por el inexorable colapso ecológico que acompañan prácticas de desplazamiento forzoso relacionadas con el acaparamiento de tierras, "las guerras desatadas para controlar las reservas petroleras y mineras, y los extractivismos (agroindustria, plantaciones agroexportadoras, incluso con cultivos genéticamente modificados) que casi siempre destruyen los medios de vida rurales y generan pobreza urbana" (Acosta, A. 2018). 
y/o en equipo problemáticas que aquejen a los educandos y a los seres vivos, por ejemplo de tipo ambiental; reconstruir el saber enseñado y/o el "apropiado" por los educandos; indagar y reflexionar sobre alguna de estas, las causas, impactos, consecuencias, las responsabilidades en el mismo, asunto que pasa por la autoconsciencia y la autocrítica; diseñar y desarrollar planes de intervención situados, entre otras actividades.

En esta vía el Operador comprensivo edificador, OCE (que ya hemos presentado como Operador conceptual, Arboleda, 2.000, 2005, 2007), se puede desarrollar a partir del concepto influyente o el acordado en la problemática ambiental y ecosistémica seleccionada; este dispositivo es pertinente en tanto moviliza operaciones, representaciones y estrategias de pensamiento, entre otras la determinación de cualidades, en especial accidentales, articuladas al concepto temático, relaciones de inclusión y exclusión, infraordinaciones y heterordinaciones; esta última representa una operación de pensamiento de orden superior propuesta en el marco de la PCE y desde la cual se establecen analogías endógenas y exógenas, razonamientos contrafácticos por supresión y por adición, y se animan proyectos (actitudes) de vida, tarea que implica la identificación en la experiencia de vida personal de límites y dificultades respecto al problema ambiental, autorreflexión, y la generación de acciones de mejora, control y prevención.

Es deseable que las actividades diseñadas para fortalecer el ACE sean recapituladas por los estudiantes, individuamente o en equipos, en las relatorías edificadoras (Arboleda, 2011ª, 2017). Todo lo cual contribuye a la negociación y reafirmación de los significados y sentidos que precisa la comprensión, en particular la comprensión ética y personalizante ${ }^{57}$. En esta ex-

$57 \quad$ No sin razón Font (2003) asevera que "la negociación de los significados juega en la construcción personal". Para una didáctica del resorte que aquí se describe y propone, el crecimiento personal que se gesta desde la escuela se afianza al promover la construcción significativa de conocimientos, que se refuerza apelando a procedimientos periencia se mueven varias modalidades tales como los pensamientos social, analítico, crítico, ético, histórico, lateral, biotecnológico, creativo, innovador, emprendedor o actuante, científico y ético, ecosistémico, dependiendo de la suficiencia del docente, entre otros aspectos, en materia del campo de conocimiento y saber disciplinar, metodologías colaborativas y de pensamientos múltiples, otra de las vastas deudas de la enseñanza ${ }^{58}$. Es esta una manera de aprender (a ser y hacer) por problemas edificadores, como procedimiento CE.

También encontramos las reflexiones sobre la historia como estrategia de aprendizaje, que Arboleda, L. C. (2011) ha liderado, desde el grupo Historia de las Matemáticas, como contribución a la enseñanza y formación de pensamiento matemático (y con repercusión en los proyectos de vida). Para ello inicia con la pregunta: ¿Cuál es el tipo de historia susceptible de ser apropiada en la educación matemática y que contribuya efectivamente al diseño de estrategias didácticas para la formación de pensamiento matemático? Tema que podríamos incluir dentro de lo que hemos denominado el saber ensimismado, que caracteriza a aquellas prácticas centradas específicamente, como la mayoría de experencias escolares respaldadas por didácticas, epistemologías y currículos cognoscitivistas, en aprendizajes y formaciones que no ayudarían mucho a resolver el problema epistemológico y didáctico que venimos ventilando sobre las deudas de la educación para educar desde y con el área cultural a fin de que se haga un uso afable de saberes y funciones mentales en materia personal, societal $y$

didácticos y metodológicos para el uso de estos en función del mejoramiento del ser personal de cada sujeto educable. $58 \quad$ La escuela (y la didáctica) aún dilata, no toma en serio el asunto del desarrollo del pensamiento. Sería importante que la formación atendiera este tema de manera juiciosa, en la que se aborden conocimientos teóricos, técnicos y práxicos sobre el particular, y sobre cómo se puede innovar en el fortalecimiento de pensamientos múltiples. Es insuficiente fortalecer la esfera crítica del pensamiento (bajo la creencia de que de esa forma se desarrolla el pensamiento), es más la actitud crítica precisa también de otros potenciales dimensionales como la creatividad, la lateralidad, el hacer, la complejidad, entre otros tipos de pensamiento. 
pluriversa. Sin embargo, no es tanto así, porque esta experiencia en lo fundamental se podría inscribir en las conceptualizaciones y prácticas de formación de saberes y conocimientos que además de potenciar conceptos a partir de procesos de recontextualización de un saber disciplinar (historia de las matemáticas y educación matemática) en otro contexto o área cultual (historia), dispone sin duda de elementos valiosos para energetizar comprensiones y algunas dimensiones potenciales del pensamiento y de la personalidad de cada sujeto educable, sobre todo porque promueve lo que podríamos denominar "una comprensión matemática de la vida" 59 .

Las relaciones entre matemática y vida son recíprocas. Si bien es cierto las matemáticas devienen vida, podríamos decir que la vida también es matematizada, afectando la manera de entenderla y su corporeidad inherente: los avances en este campo logran cada vez impactar más aquella, con la idea básica de aportar a su desarrollo, modificación y creación (de nuevas formas de vida) desde otros campos ligados a las ciencias naturales y exactas. La matematización de la vida ha llegado a tal grado que sus saberes han participado no solo en la construcción del código genético, en la decodificación de la constitución del ser humano, la vida y la existencia (vueltos texto informativo), también en los procesos de digitalización (a partir del código), "que ya no solo operan sobre los datos de los sujetos puestos en máquinas y dispositivos desde su exterioridad, sino al adentrarse en la posibilidad de hacer visible la naturaleza de la corporalidad y de la vida como un código textual y matemático", y en este curso "ha posibilitado la emergencia de una nueva episteme anclada en la vida como información" Rodríguez, R. (2012), contextualizado por Riveros (2020). Incluir es-

$59 \quad$ Con ello se alude al direccionamiento y vigorización de potenciales matemáticos en y desde la vía de la vida y de la historia como discurso de la existencia y la vida, más que a la posibilidad de reflexionar y comprender mejor la vida desde el saber y el pensamiento matemático, pretensión que no se descarta aquí. tos fenómenos y hechos históricos es una de las apuestas que ocuparán mucho más a la didáctica como saber disciplinar y campo plural, a la epistemología y a la educación incluida la matemática. Es esta otra argumentación que aporta en la pertinencia de la historia como terreno que no se puede objetar en las conceptualizaciones y prácticas educativas.

En cualquier caso, el uso de la historia como hechos de vida y de existencia convencional y digitalizada ${ }^{60}$, es fundamental en los procesos de enseñanza de los diferentes saberes, porque, además de las razones expuestas, representa una manera de responder a la tendencia global de dominación del discurso histórico a través de la imposición de memorias y olvidos como estrategia de invisibilización de ciertos hechos; por otro lado, porque permitiría lograr mayores grados de comprensión conceptual, si incluyera la comprensión de los procesos de constitución de los mismos, así como de algunas estrategias didácticas empleadas históricamente para intervenir en su apropiación. Extrapolando la idea de Thurston (citado por Arboleda, L. C., 2011), la educación no podrá obtener progresos sustanciales en sus propósitos si no entiende la naturaleza de los saberes enseñables.

En este curso, la reflexión sobre la formación con el concurso de la historia, al menos en el caso que estamos exponiendo, va más allá de aquellas perspectivas y prácticas de formación que aunque se mueven en el esquema saber hacer, poco se regalan la oportunidad de generar situaciones de aplicación, uso y vivenciación del conocimiento en otro ámbito del conocimiento, como es el caso de la historia como disciplina cultural y curricular, precisamente en alguno de los marcos en que ésta se manifiesta, que permita establecer una mejor relación interdisciplinar. Dicha reflexión representa una manera de

60 Según Riveros (2020), la vida digitalizada es un espacio social en el que se entrecruzan los signos biológicos con los símbolos culturales en una mediación e interacción permanente que configura a nivel interno y externo eso que somos. 
intervenir, con independencia de una explícita consciencia o voluntad, en la formación de saber ser (que implica el hacer), inclusive de saber hacer para ser o saber ser otro, pues el sujeto educando, a partir de estrategias mediacionales y propias, vive experiencias, no solo cognitivas y operativas en la reconstrucción del peso empírico (las condiciones históricas y epistemológicas como realidad profunda y no axiomática) de las teorías, de las huellas de actividades de razonamiento humano con sus respectivas ideas y creencias, dudas y errores, argumentos intuitivos y heurísticos, incertidumbre, controversias y aproximaciones alternativas que subyacen a la constitución de objetos matemáticos como los números reales (Arboleda, L. C. y otros, 2019), que aguzan desempeños de saber en tanto aquel debe negociar significados matemáticos con significados históricos, lo que deriva en una resignificación de conocimientos y conceptos, sino también fenómenos de crecimiento personal, en tanto optimizan una consciencia cognitiva, histórico- social, crítica, propositiva y actuante.

Otra cuestión es que indagaciones de este tipo expresen (quizás no sea éste el caso) una manifiesta aspiración de saber ser siendo, mejor, la pretensión de saber hacer para ser. Lo cual sería definitivamente una manera de enseñar educando vía el cultivo de pensamientos múltiples (matemático e histórico, al menos), comprensiones múltiples (histórica, social y semántica ${ }^{61}$ ), en especial, y tangencialmente las comprensiones ética y edificadora, así como la pluridimensionalidad del sujeto (las dimensiones cognitiva y socio histórica, entre otras que lo configuran de manera radical), según se esclarece cada una en este texto ${ }^{62}$.

$61 \quad$ Esta incluye la comprensión global que el profesor de matemáticas adquiriría y promovería en sus alumnos al realizar la reconstrucción o complejización de la simplicidad que constituye el conocimiento o concepto matemático objeto de abordaje.

62 Respecto al dimensionamiento humano del sujeto y con base en los postulados intencionales que Arboleda, L. C. y otros (2019) expresan a partir de estudios adelantados en el marco de programas de licenciatura en torno a los alcances de "hacer matemáticas" a la luz del conocimiento
Vincular apropiadamente la historia o el conocimiento histórico al currículo de algunas asignaturas para reconocer la trayectoria humana que acompaña la formalización y objetivación de los conceptos, alto descuido en una escolaridad subsidiria de didácticas inerciales, es una forma de humanizar el saber disciplinar y la práctica de enseñanza, de ir por otro lado de la enseñanza sacralizada y dogmática, sensibilizando más el aprendizaje y al educando.

Una razón es que este acercamiento se instala en el lugar de lo que podríamos llamar "relación de lo fáctico-refactico $(F-R)$ " : los saberes enseñables son fenomenológicos en tanto se urden a partir de eventos de la realidad natural y social (aspecto fáctico), y su apropiación comprensiva precisaría el aspecto refáctico $1(R 1)$ que es la recontextualización o reconstrucción histórica de la actividad humana -- singular por cierto en cada campo de saber-- que fundamenta su configuración (las concepciones y acciones sesgadas y afortunadas de los actores), tanto como la (re)contextualización relacionada con la aplicación y uso de aquellos en situaciones

histórico que se ha de apropiar y usar, la intervención educativa equipada del hecho histórico potenciaría algunas de las dimensiones que configurarían la personalidad del sujeto educable, tema que hemos retomado en distintos momentos de esta exposición, entre otras la dimensión (léase, actuación) cognitiva, epistémica y social, que incluye "leer, escribir, escuchar, buscar fuentes, discutir, analizar y hablar sobre las Matemáticas"; afectiva, axiológica y actitudinal, en tanto promueve en el educando, además de disposiciones, valores como la sensibilidad, tolerancia y respeto hacia maneras no convencionales de expresar ideas o resolver problemas, valoración de la persistencia y el ánimo ante la adversidad (...)"; la misma dimensión histórica y cultural en tanto aquel podría experimentar "un cambio en la manera habitual de abordar la educación en Matemáticas, en el modo de promover el pensamiento de los individuos, o en la consciencia sobre el estilo de enseñanza, debido al cambio epistemológico que se genera para los conceptos matemáticos, y también porque propicia la contrastación de hechos históricos con la realidad social presente del educando; la dimensión política, por cuanto fortalecería "la valoración y el papel de la profesión docente"; y en parte la dimensión ética, por la posibilidad de "imaginar cómo es la forma de razonamiento de otro (su alumno) y escucharlo". Todo ello es una muestra de la humanización de la epístemología, la pedagogía, la didáctica, la educación y enseñanzas ligadas a las matemáticas, que nuestra PCE reclama a los diferentes campos del saber y del conocimiento educativo. Una experiencia reflexiva que de algún modo matiza nuestra ocupación frente a la idea de enseñar educando. 
ideales, imaginarias o reales que incluyan la vida, sea personal, social, histórica, cultural y demás, y los ecosistemas (R2). En el aula regular es recurrente la ausencia de $R 1$ y/o $R 2$, en el cual se ubica el acercamiento matemático en referencia, y más aún de $R 3$ relativa al uso humanitario del conocimiento y por la cual el comprendedor asume una comprensión ético estética a favor de la vida.

Aportaciones como ésta por parte de la DPV promueven aprendizajes por comprensión, CE ${ }^{63}$ y paralelamente reafirman la inconveniencia de centrar el primado de la didáctica en los saberes, en contenidos o en los aprendizajes, y menos con el máximo propósito de permitir a los individuos responder a las exigencias generalmente predeterminadas del mundo en el que viven; orientación esta, de alto vuelo aún, que dificulta las posibilidades de mayoría de edad ótrica que la geografía de la vida y un orbe más humano no exentos de conflictividad reclaman a la educación y a los saberes que la abordan, según se ha examinado en otros segmentos de esta exposición. Formar-se para resolver problemas que impone el modo prevaleciente de relación social (que condiciona la estructura del pensamiento humano e induce la mente no racional y la manera de desenvolverse en la vida), es un pensamiento didáctico y educativo que aunque es necesario para la transformación individual y societal, sirve más al régimen del (sobre)consumo que lo obliga como término, más que de personalización, de existencia, superviviencia y desarrollo productivo, haciendo a los individuos e instituciones rehenes en esta tarea.

La realidad, que de acuerdo con De Sousa S., B. (2020), siempre va por delante de lo que pensa-

$63 \quad$ No obstante sus limitaciones para promover enseñanzas que eduquen, las didácticas semánticas y por competencias influyen no solo en esta ciencia sino además en las enseñanzas y los aprendizajes. La PCE y su correlato la PPV hacen parte de las perspectivas emergentes que median por una enseñanza y un ACE que enfrenten el actual proyecto educativo, cómplice del hominicidio que desata y naturaliza el proyecto de desarrollo moderno, sembrado en los intereses individuales. mos o sentimos sobre ella, es que los propósitos fundantes y más sentidos de la educación están, por el contrario, del lado de una formación para afrontar los conflictos (que son pluriversales), y resolver, predecir, ralentizar o evitar el surgimiento de problemas y fenómenos que puncen la realidad humana y planetaria. La educación para la mayoría de edad ótrica hace referencia a la formación que propugna por gravitar sobre la evolución pluridimensional y compleja de los individuos, crucial para que estos procedan con pensamiento detenido, analítico, comprensivo y con responsabilidad ética ante las demandas de la vida humana y del tejido ecosistémico. La educación para una supuesta mayoría de edad ensimismada fecunda, antagónicamente, el universo de la gestión económica y empresarial, que se reproduce con la actividad de agentes resolutores y competentes para hacer en favor de la rentabilidad productiva ${ }^{64}$. Crecer en CE es un logro de mayoría de edad, una experiencia que aporta sabiduría, entendida esta como potencial mediante el cual ganamos experiencia de saber ser otro.

Toda relación social establece determinados tipos, modos y características de formación, enfilando en esa vía la educación. En las relaciones de "uso y desecho de productos" que caracterizan la época actual en razón de asegurar el retorno exponencial y alienante de las inversiones, la educación que impera es la que favorece potenciales (ahí el conocimiento y el saber) para que las personas sientan, piensen, vivan y pro-

\footnotetext{
$64 \quad$ Los aprendizajes para la vida humana que debe procurar la educación, en el lenguaje en que hemos venido reflexionando, no son exactamente los mismos que demanda el modelo protervo de consumo: una diferencia estriba en el acento que se ponga. Los aprendizajes y la formación en una sociedad como la actual elevan dimensiones del ser que aseguren el delineamiento de conductas que no contradigan el orden establecido. La convivencia societal y tecnoplanetaria pugnará, por el contrario, por una educación que favorezca, no forzosamente el desarrollo de competencias para el rendimiento sino de facetas del individuo que le posibiliten crecer en consciencia comprensivo edificadora, es decir actuante, ética, por la cual puedan usar sus comprensiones en favor del hombre, la existencia y la vida, en la conquista de espacios que limiten el impacto de la ortodoxia económica, tecnocientífica e inclusive filoempírica, casi siempre perjudicial para estos.
} 
cedan en el marco de las mismas; el acontecer de la gran mayoría de las personas, en esta forma de convivencia se hace precaria, inclusive para quienes más se beneficien de este modo de relación, dado que son siervos unos y otros del uso utilitarista de aquellos; así, la educación estaría obligada por encima de la ética a reforzar tales condiciones de vida.

La vida clama por una formación que haga de la otredad el cemento de las enseñanzas y los aprendizajes, para que los sujetos de la relación educativa lideren, sean vectores de experiencias de transformación personal frente a las relaciones de sujeción deshumanizada reinantes. Aspecto este que profundiza la imperiosidad de que el acogimiento permee la didáctica para que cuestione y obre con miras a establecer fronteras precisas a la generación de saber nocivo y al uso pernicioso del conocimiento, y responda al llamado educativo de erigir los proyectos de vida que puede ofrecer la educación para una interacción más humana en la existencia. Una didáctica como praxis definitiva en el empeño de hacer de la enseñanza un acto que educa, genuinamente formativo, civilizador.

En relación con el fortalecimiento de proyectos de vida, máxima de las enseñanzas y formaciones que educan con autenticidad, la DCE asume estos de modo concreto, diferenciándose de narrativas superfluas que los conciben como una proyección idílica de vida armónica, y/o del orden escatológico, para ser y proceder en (y/o más allá de) la existencia. Los proyectos de vida del educando han de ser tomados como una serie de propósitos ajustados a planes y actitudes que, en virtud del toque pedagógico, va generando, desarrollando, evaluando y reorientando en su devenir el mismo individuo, de acuerdo a sus propios movimientos, tiempos, ritmos, intereses, barreras, valores, sueños, pensamiento y otras particularidades, para consolidar su propia autonomía en una realidad contingente, impredecible, imprevisible, incierta, que le permita estar un poco mejor preparado para lo que pueda o no suceder, ser o no ser; se refiere al ingrediente de posibilidad que ha de estar presente en los planes aterrizados que los intervinientes propongan para decidir su propio camino y enfrentar de esa manera el ser siendo heterónomo, impuesto por fuerzas homogeneizantes, exógenas a sí mismos, y el cual generalmente padecen quienes no tienen capacidad de autoproyección o no han sido educados para ganar fortalezas de frente a visionar su camino en la vida, y en consecuencia son arrojados a vivir proyectos negativos de muerte ${ }^{65}$.

La educación puede crear la opción a los educandos para que aprendan a construir sus proyectos y planes de vida, de acuerdo con sus propios criterios. Es esta una manera de intentar reconectar la política y la ética con la ciudadanía. El acto de educar pasa por ofrecer experiencias, conocimientos y una gama de posibilidades para que el educando construya criterios y formule metas relacionadas con las dimensiones de la personalidad humana y las esferas de la vida y la existencia en las que él desee intervenir. Por ejemplo, frente a la dimensión social la escuela ha de mostrarle al estudiante los significados de ser social y cómo puede crecer más en esta dimensión, cómo la misma es afectada por ciertas formas y sistemas de relación, y lo que ello significa y precisa: animar reflexiones sobre la importancia de ser (y cómo se podría ser) más comunicativo, más solidario, más participativo, menos egoísta, menos invasor del otro y de lo otro, animando en él la toma de decisiones para que asuma actitudes en esta esfera, planes situados, es decir factibles, terrenales, que consid-

\footnotetext{
$65 \quad$ Los proyectos de muerte se traducen generalmente en ausencia de propósitos, en actitudes negativas ante la vida y la existencia. Pero no todo proyecto de muerte es negativo. Los proyectos o actitudes de y por la vida incorporan la posibilidad de morir con dignidad, una actitud permanente que dignifique la vida y la muerte. Un proyecto de muerte positivo es la proyección que incluye la muerte en sus prospecciones vitales, la muerte no como ausencia o probreza de vida, sino como consciencia de la finitud humana, de cuidado de la vida propia, del otro y de lo otro. Un asunto ausente o efímero en la educación, la pedagogía y la didáctica.
} 
eren la imprevisibilidad, cruzados por la ética y la actitud política (que también son dimensiones del ser), entre otras que tendrán lugar de acuerdo con las metas y objetivos de la autoproyección.

Todos los profesores pueden aludir a la dimensión social sin que ello constituya un diálogo al margen de los temas objeto de estudio. Puede insertar algunos temas de clase en la esfera social de varias maneras: sea consultando sobre los investigadores relacionados con la información o tema de abordaje académico, examinando su momento histórico, político, social y cultural, y contrastándolo con el actual a modo de reconstrucción histórico-social del saber; bien identificando escenarios sociohistóricos en los cuales se pueda aplicar o conectar el conocimiento en referencia; dando cuenta de los beneficios y perjuicios que ha traído o puede acasionar un malsano uso de este en algunas de estas dimensiones, incluida la social, y a partir de allí reflexionar de manera crítica y creativa sobre cómo el estudiante puede articularlo a su propia vida y cómo puede provocar en sí mismo y en su entorno prácticas saludables con su saber hacer. Siendo esa una forma de conferirle mayor significación y vida a lo que se aprende, una manera de aprender siendo, humanizando el saber, afirmando el saber ser, un original saber siendo que impacte positivamente en los proyectos de vida de los educandos. Una enseñanza que educa, que alimenta el pensamiento comprensivo como potencial múltiple en virtud del cual los educandos construyen y dirigen subjetividades edificadoras.

La función de educar hace parte del orden filosófico de los distintos campos que giran alrededor de la educación, y que los funcionarios de esta han soslayado instrumentalizando el quehacer educativo. La didáctica no debería seguir respondiendo solamente a las demandas del establishment, el cual termina agregando y en consecuencia direccionando la acción edu- cativa sobre la vía de la soberbia ontológica que totalitariza al "yo", detonando el egoísmo, el individualismo que siempre deviene proyecto de muerte, sometiendo cada vez más al otro y lo otro, impidiendo la acción del yo incluyente, acogiente, ótrico, pluriversal, y el movimiento contrario en el que opera la imposición ética del otro en los yoes, según asumimos aquí el probema de otredad en la educación; no debería explayarse hacia el desarrollo de competencias para que los docentes y estudiantes respondan desde sus dominios cognoscitivos, motivacionales y operativos, a los retos sociales que aprecia el sistema de las finanzas. La didáctica "sentiente" enfrentará la desorientación teleológica educativa promoviendo prácticas de enseñanza y formación que infundan "sabiduría", uno de los fines de la educación propuesto por Whitehead (1957), en el sentido de "saber usar bien nuestros conocimientos y habilidades. Tener sabiduría es tener cultura y la cultura es la actividad del pensamiento que nos permite estar abiertos a la belleza y a los sentimientos humanitarios."

Cerca de esta deseabilidad despunta la didáctica crítica, tal como se ha expuesto hasta aquí, y la didáctica discursiva ligada a esta, en particular el análisis crítico del discurso (ACD) ${ }^{66}$, que al lado de la razón crítica pone dispositivos teóricos y metodológicos para la formación escolar de sujetos dialógicos, analíticos y propositivos, sobre todo en una civilización como la nuestra donde el discurso (oral, escrito, verbal y no verbal) se halla colonizado, de acuerdo con Fairclough (2008, P 181), por la publicidad, que está más del lado del poder económico

\footnotetext{
$66 \quad$ Enfoque entendido, de acuerdo con Fairclough (2008), uno de los fundadores del ACD, como el análisis del discurso que pretende explorar sistemáticamente las relaciones a menudo opacas de causalidad y determinación entre:

(a) prácticas discursivas, eventos y textos

(b)estructuras, procesos y relaciones sociales y culturales más amplios para investigar de qué modo esas prácticas, relaciones $y$ procesos surgen y son configuradas por las relaciones de poder y en las luchas por el poder, y para explorar de qué modo esta opacidad de las relaciones entre discurso y sociedad es ella misma un factor que asegura el poder y la hegemonía.
} 
y sociopolítico que de la vida. Como se mencionó al inicio, si bien las didácticas críticas dejan ver en sus reflexiones, planteamientos y propuestas teóricas y metodológicas el escenario desvalorizante de la vida en función de intereses, no han provocado una alteración capaz de lograr en la práctica una conexión entre enseñabilidad y educabilidad que derive en el acto de enseñar educando, para que el sujeto educable experiencie un sentimiento moral y un talante fraternal con lo que aprende, resignificándolo en sus vuelos de emancipación fallidos y exitosos.

A mi modo de ver las perspectivas sociocríticas son relevantes pero no suficientes para la formación que está del lado de la función de educar. Por definición se ubican en el sujeto y/o en la sociedad, y a partir de allí enfrentan lo que afecte a estos. La orientación crítica concentra su atención en la dimensión psíquica del individuo, sobre todo en la formación de la razón crítica, bastión que, como se expresó hace poco, logra vincular los mundos subjetivo y el objetivo. Aunque no se dicuten las cualidades de esta función para una educación hacia la libertad, la función de educar reclama una intervención en la formación del sujeto en su pluridimensionalidad (que incluye la razón crítica, yendo más allá de los componentes cognitivo y social; por ejemplo, la no razón, otras actitudes diferentes de las críticas, las corazonadas, y en general las distintas dimensiones). Aportar en la formación de mejores seres humanos (sentido álgido de la función en referencia) requiere una enseñanza en la comprensión, una comprensión actuante que vaya más allá de la interpretación y la consciencia, que forme, que edifique, lo que supone formar también en otras esferas ya mencionadas de la personalidad del individuo, que al interactuar con la razón crítica den lugar a una comprensión que haga, actúe, forme, humanice. La razón crítica será relevante para formar seres autónomos, pero la formación de seres que además sean solidarios y pluriversos demanda más que este potencial una consciencia, mejor una comprensión, un pensamiento comprensivo expresamente dignificante, sobre el cual no se pueda enquistar la razón despótica del mercado, que encuentra de ese modo en la razón sociocrítica un fundamento (un aliado) discursivo importante para sus nociones de libertad, de individualidad, de soberanía aplicadas al mercado ${ }^{67}$.

Es necesario avanzar más de la mano de la educabilidad, que tiene que ver con el acogimiento, no en el solipsismo racional o dependencia de la razón, sino en la pluridimensionalidad, lugar desde donde interactúán las funciones psíquicas, ahí la razón, el pensamiento, la inteligencia, la sensibilidad, los sentimientos, la intución, además de las esferas social, ambiental y estética, entre otras. El asunto sería cómo generar educabilidades para el crecimiento plural del ser, para que docentes y estudiantes vivan sus comprensiones ético críticas usándolas en su entorno escolar y extraescolar, es decir para que maduren en pensamiento comprensivo edificador; por lo que nuestra apuesta se enfila hacia la formulación de un constructo que promueva una nueva manera de indagar, conocer, apropiar, aplicar, generar y usar conceptos, conocimientos, procedimientos y saberes, valores y actitudes.

Es el caso de las apuestas de la DCE, desde la cual se reflexiona y abona conceptos y estrategias encausados histórica y espacialmente

\footnotetext{
$67 \quad$ Poco es ajeno a los intereses y poder del ordenrazón-saber globales. Esta macrodeidad pretende asimilar a su jurisdicción inclusive los proyectos y sentimientos liberadores, ahí la pedagogía y la educación crítica, social, ambiental, científica y todos aquellos que crean escenarios para vivir de manera más humana, lográndolo cuando estos presentan debilidades para su corporizacion objetiva, para transformar realidades; genera ella misma y promueve discursos sin voz o en los cuales impone su propia voz. Es una racionalidad que intenta someter a los agentes racionales y aún los proyectos edificadores a un proceso de elección, evaluación o justificación racional, uniforme y estandarizado, negando el carácter plural de la misma racionalidad (que a veces da lugar a relativismos epistémicos de los cuales se aprovecha la misma)
} 
para la enseñanza y la formación, tales como las que se recogen en este capítulo, dirigidas a potenciar una educación, enseñanza, formación y aprendizajes que formen un sujeto otro, con una fuerza CE en la cual éste y los objetos con los cuales trata en su devenir se relacionan y transforman. La experiencia CE como tesoro didáctico, resignifica la relación, digamos biológica, del sujeto con el objeto, la connivencia entre los mundos subjetivo y objetivo, el sujeto y lo empírico; en virtud de esta fibra ontológica se afectan uno y otro mundo. Más allá de Kant (2003), la CE supone un medio para la conquista de mayoría de edad del sujeto, una ruta hacia la edificación de sí mismo, el alcance de otra edad para la otredad.

La DCE se asienta sobre la PCE de la educación y la formación para contribuir con vocación humanitaria en la emergencia que sacude a la educación, a la pedagogía y a la vida ecosistémica. Entre los constructos que alimentan esta perspectiva $^{68}$ se halla, como hemos visto, la misma didáctica sociocrítica, el análisis crítico del discurso, amén de ópticas emergentes con las cuales se ha dialogado aquí, como la perspectiva radical e inclusiva (Herrán G. A.), la pedagogía de la alteridad (Ortega R., P) y la pedagogía mesoaxiológica (Touriñán L., J. M.). No basa sus desarrollos indagativos y metodológicos en supuestos conductistas, cognitivistas o constructivistas sustentados en la psicología del aprendizaje principalmente, aunque no se resiste a algunas de sus contribuciones. Parte de la idea implícita en la PCE según la cual el dominio didáctico ha de orientar sus progresos teóricos, estratégicos y metodológicos sobre los actos de enseñanza y aprendizaje en sintonía con la función de educar, si se prefiere, ha de afirmar los potenciales de enseñar educando, enorme deuda histórico, social, cultural, ecológi-

68 Dirigida a tributar conocimiento de la educación, especialmente en los procesos que atraviesan los actos de conocer, enseñar, aprender y educar. En el terreno de la función de enseñar educando la PCE arroja luces para recorrer caminos hacia una didáctica comprensivo edificadora. Enseñar educando desde una perspectiva CE. ca y política de la didáctica y la educación.

En correspondencia con el llamado expresado inicialmente a construir una episteme comprensivo edificadora que haga de la didáctica no un acicate para eternizar los órdenes que en aras de la concentración de la riqueza generan mayor desigualdad, inequidad, injusticia y pasividad en los individuos, sino un visor activo de la enseñanza, una disciplina que a la luz del erosionado sentido humanizante de la educación promueva aprendizajes situados y realmente fraternos; la PCE inyecta elementos teóricos y metodológicos (algunos ya expuestos) dirigidos a develar una perspectiva didáctica ajena a la racionalidad que subyace a la disciplina y el quehacer didáctico. Esta didáctica se sustraerá de la noción de la didáctica moderna centrada en el saber por el saber y el saber hacer eficientista (asunto técnico), en una ególatra enseñabilidad (mismidad, fragmentación, secuenciación y deshistorización) del saber, y se enfila hacia el saber para ser más humano, o el saber siendo otro (humanización del saber y por supuesto de la didáctica).

Será una didáctica ligada a la historicidad de los individuos que están siendo en tiempo presente. Una didáctica que vele por la reapropiación de la temporalidad personal, escolar y social cada vez más acelerada (líquida), sincronizada con los tiempos de los individuos y su acontecer; lo que implica, según Gaete (2015), desarrollar una comprensión hermenéutica de los sujetos y sus acciones, es decir, abordar las "preguntas sobre el 'qué', el 'por qué', el 'quién', el 'cómo', el 'con' o el 'contra quién' de la acción didáctica y de la educación [...] [implica] tener la competencia que se podría llamar comprensión práctica". Una didáctica para el desarrollo de pensamiento comprensivo edificador, personalizante, hacedor de subjetividades otricas en las cuales crece el ser autoconsciente, autocrítico, autoconstructivo, sociocrítico, histórico, ético, ciudadano del pluriverso, que hace del pensamiento compren- 
sivo un modo edificante de vivir, de ser sentipensante.

La DCE orienta sobre cómo los aprendices pueden organizar y resignificar lo que aprenden para agenciar proyectos por y para el cuidado de vida personal, social, planetaria, resolver y prevenir problemas de su existencia, generar ámbitos de inflexión, y en general para proceder en la vida, lo que fuerza también el cambio de formatos rígidos de la enseñanza y el aprendizaje: en este caso los profesores diseñan proyectos y talleres de CE, así como las actividades cognoscitivas, metacognitivas y edificantes involucradas en estos, poniéndolos en consideración de los estudiantes quienes apoyan en la configuración de los mismos, los desarrollan individualmente y/o en equipos; igualmente este constructo orienta y anima la irrigación de conductas éticas, críticas, valóricas y propositivas, más que esperar respuestas únicas propias del aprendizaje pasivo. No todo aprendizaje desemboca en saber ni hacer, ni mucho menos en saber para ser mejor persona. Muchos aprendizajes, por más que signifiquen, que sean apropiados, subjetivados, quedan ahí, haciendo parte, aún crípticamente, de nuestra historia, pero hay otros que redireccionan esta, y otros pocos que la engrandecen; son estos últimos los que persiguen las enseñanzas que educan en la libertad y la humanización de sí mismo, del otro y de lo otro.

De esta manera la PCE avanza, tanto como la Pedagogía mesoaxiológica, de cara a aportar conocimiento de la educación, que fundamente el significado de la educación, la construcción de ámbitos de educación y la generación del diseño educativo, que, de acuerdo con Touriñán (2017), "son conceptos nucleares de la competencia para la función de educar", centrada en la formación de mejores seres, que al saber guiar sus actuaciones bajo mínimos éticos y no solamente en sus intereses individuales, sean protagonistas en la construcción de mundos más nobles. Responde a la exigencia de formación de un docente con mirada crítica y actuante frente a la lógica de la institución y del sistema educativo, de los lenguajes y gramáticas que han legitimado la escuela como institución disciplinada, de los bloques de poder interesados en que ésta reproduzca comportamientos $y$ prácticas pasivas e insolidarias; un docente que participe con pasión y de manera innovadora en la refundación de una escuela abierta e independiente; un docente que no se supedite a la lógica de la industria, del consumismo efímero (usar y desechar, inclusive el conocimiento "fiable") y del dinero (acumular por sobre todas las cosas) -- la cual, reiteramos, privilegia más una educación técnica (formar futuros trabajadores del ordenamiento), reacia al cuestionamiento, incapaz de transgredir las normas morales plantearias del mercado, que forma en conocimientos prácticos, valores y actitudes para el incremento de la rentabilidad financiera, rasgos propios de la educación que se impone en nuestra sociedad del eufemismo, la desinformación como virus ideológico y el conocimiento utilitario --, que una educación basamentada en lo humano (orientada a formar mejores personas, artífices de orbes de vida), que conecte al estudiante con una visión desacralizante de proyectos individualistas que se enmascaran en causas sociales. Un docente emancipado de las lógicas de enseñabilidad del saber y su programación temporal (que él debe naturalizar), y de los aprendizajes esperados, donde se pone al estudiante como centro de un proceso secuencial, fragmentado y uniforme. Un docente y una escuela generadores de culturas escolares emergentes, CE.

Superar la didáctica moderna, incrustada aún en la tríada pedagógica o modelo didáctico categorial "maestro, saber, discente" que mantiene en estado de ficción ${ }^{69}$, de minoría de

$69 \quad$ En tanto omite otros actores de la complejidad didáctica, ahí la persona o pluridimensionalidad del maestro y del discente, sus singularidades y temporalidades, su contingencia, historicidad y contextualidad, el poder, los medios y métodos, los fines radicales de la enseñanza, de la educación y saberes asociados, entre otros. 
edad a nuestra educación y saberes inherentes, implica dotar de vida las relaciones formativas, aceptando que en el encuentro didáctico no sólo se ponen en juego saberes, habilidades y comprensiones sino las historias de vida, los contextos socio-históricos y políticos, los sueños, expectativas y pluridimensionalidad de los sujetos involucrados. Al equipar su programa con este ingrediente, la didáctica se vivificaría y estaría ocupada en brindar la reflexión y generación de las herramientas que faciliten a la escuela encarnar un rol realmente formativo que posicione a los participantes del acto pedagógico como artífices ético-políticos en la conquista de escenarios para su vida personal, social y planetaria, recios y propositivos antagonistas de las acciones que atenten contra el tejido de la vida digna, convirtiendo sus procesos educativos $y$ formativos en laboratorios actitudinales de los cambios que apremian al mundo para vivir humanamente (Arboleda, 2019b).

Tal didáctica afirmaría la formación del sujeto como persona, como ser relacional y sistémico, cada vez más digno, que aprende y se forma con el ejemplo de acogimiento incondicional que le brinden el educador, la escuela y las instituciones del estado, y que con su propio ejemplo se humaniza y abona a la dignificación de la existencia. El papel de los profesores es crucial para este cambio de enfoque y del panorama lúgubre de la educación. Dependerá, en buen grado y según hemos manifestado en otro espacio (Arboleda, $2019^{a}$ ) y para decirlo también con Rouse (2009), de lo que el profesorado "sepa" (sobre cuestiones teóricas, políticas y legislativas), "haga" (pasar de los conocimientos a la acción) y "crea" (en su disposición para apoyar a los menores). Una didáctica de esta condición sería una gran influencia para que el docente posicione su quehacer, más que como práctica pedagógica, como una praxis formativa, edificante (Arboleda, 2019c), según se explica enseguida.
La PCE permitiría a la didáctica y sus niveles de reflexión, al campo que observa el universo didáctico ${ }^{70}$ y al mismo currículo, desarrollar sus objetos de acercamiento en torno a las situaciones de enseñanza-aprendizaje de modo que a la postre sirvan al docente para concebir la práctica de enseñanza como práctica formativa, haciendo de ésta una praxis formativa comprensiva que se reafirme en el acogimiento sentido del sujeto educable. La ética de la alteridad, del entrañamiento ótrico, se sitúa en el epicentro de la oportunidad regeneradora y transformadora proporcionada por esta perspectiva de la pedagogía, la didáctica y la educación. En el caso del docente, éste gana, en un movimiento que no es rectilíneo, grados de praxis formativa desde el momento en que despliega una postura crítico propositiva frente a su propio quehacer.

Así, cuando hablamos del carácter ético de la educación y la pedagogía nos referimos a la praxis, no sólo a un discurso encerrado en la pura reflexión o ejercicio intelectual elocuente, sino y ante todo a las acciones de comprehensión, de entrega ótrica y concreta consubstancial a la función de educar. La praxis formativa es el radio donde se concreta la inclusión edificadora -- toda educación es, o debería ser inclusiva, es decir "acogedora" --, cuando el educador adelanta su intervención al vaivén cadencioso de la consciencia crítico actuante que desarrolla con base en una disposición absoluta ${ }^{71}$. Cuando el estudiante no encuentra en la docencia y

\footnotetext{
70 Según Peterssen (2001, p. 25), citado por Runge(2013), los niveles de reflexión práctica están dados por la praxis/profesión, la teoría (investigación, reflexión, teorización) y la metateoría:

- La praxis didáctica es el conjunto de todos los fenómenos y procesos experienciables del enseñar (Lehren) y el aprender.

- La teoría didáctica es la totalidad del pensamiento referido a la praxis didáctica, en donde la teoría sería precisamente el resultado de tal pensar y contendría enunciados sistemáticos acerca de lo que efectivamente es la enseñanza o cómo podría o debería ser.

- La metateoría didáctica es la totalidad del pensamiento relacionado con las teorías didácticas referidas a la formación (Bildung), la cual lleva a enunciados sistemáticos acerca de cómo y para qué se desarrollaron y configuraron las teorías didácticas; es decir, sobre cómo podrían o deberían ser.

71 Arboleda, J. C. (2019c), pag 13
} 
la escuela el acompañamiento adecuado para animar aprendizajes semánticos y por comprensiones, en particular $\mathrm{CE}^{72}$, puede decirse que ha habido una inclusión a debe, fragmentada, en la que éste ha logrado hacer parte de la institución escolar pero se halla excluido de la hospitalidad que le concierne al docente y a la escuela. Una exclusión que participa en el proyecto moderno de ruptura de la urdimbre del saber y la vida.

Digamos que la CE como visión emergente, compasiva aboga porque la didáctica desarrolle una episteme para la vida, ilumine sus aproximaciones en atención a la humanización de la existencia, ubicándose esta en el alma de la enseñanza y no solamente el sujeto epistémico y los aprendizajes. En esta posibilidad de episteme edificadora que promueve la PCE y en virtud de la cual la pedagogía y la didáctica asumirían un rol activo en la reconstitución del tejido saber - vida, es relevante la metáfora del parto pedagógico (Ortega, 2017; Arboleda, 2015, 2019). En virtud al acogimiento ótrico, incondicional del sujeto diverso -- inherente al acto de educar -, la educación, además de constituir un pacto, cobra ribetes de lo que pudiera llamarse parto pedagógico formativo (PPF), que ha de tener ubicación en el plano institucional y el que se ha de asentar en la realidad concreta del aula. Veamos.

El parto pedagógico se refiere aquí a la heterotopía (expresión de Foucault, 1967) o acontecimiento edificador que tiene lugar en el espacio educativo, orientado a concebir al educador y al educando como nuevas criaturas de una educación y pedagogía otras, es decir orientadas bajo principios sentidos, humanizantes ${ }^{73}$. La $72 \quad$ Sobre estos y otros instrumentos de la PCE que contribuyen a una entrega íntima, puede verse: Arboleda, 2000, 2002, 2005, 2007, 2008, 2011, 2016, 2019).

73 Las pedagogías convencionales dominantes se hallan en estado de sí mismo, de enseñar, instruir, formar aprendizajes y saberes, no personas. Son campos de saber de una educación que no educa, que no es ótrica, que no humaniza; mismos y no otros, ótricos. El movimiento de la mismidad es humanamente involutivo, porque no es solidario, no promueve la ética de la alteridad; contrario al movimiento de otredad. educación y la pedagogía para la vida y para enfrentar las adversidades y conflictos propios de la existencia, impone un doble parto pedagógico formativo: uno en el seno de la institucionalidad, referido a concebir al educador, y otro en el cuerpo concreto del aula, en el cara a cara docente y estudiante, en el cual este último devendría educando; uno institucional y otro áulico, personal ${ }^{74}$.

$74 \quad$ En el primer parto, el saber y la acción pedagógica han de motivar (diseñar) ambientes para que la institucionalidad politica genere acciones y direcciones en las que se formen profesionales que enseñen educando. Tal parto en el seno institucional precisa orientar formaciones bajo principios pluriversos de cuidado y respeto al complejo interrelacionado y activo de seres vivos y no vivos (personas, culturas, seres inorgánicos, etcétera) que constituyen la existencia. Formar, gestar educadores en potencia y en ejercicio como mejores ciudadanos del pluriverso e idóneos procreadores de educandos comprensivo edificadores.

Sólo alcanzan a emerger como educadores los docentes que logran apropiar el acto de educar como un parto edificador, cuando desean y se preparan para "concebir" en su propio seno al otro del rostro herido (Levinas) urgido de educación, dispuestos a reaprender de manera permanente para reconocerlo en su unicidad e intervenir de modo idóneo en la construcción cognitiva, metacognitiva, operativa y personalizante de conocimientos, en la formación de valores y actitudes por la vida -- no justamente para el mundo de hoy, inmensamente reluctante en calidad de vida --; para hospedarlo y habitarlo en su fragilidad y necesidad, sentirlo como su propia piel, protegiéndose a sí mismo, sin dejar de observar y analizar el proceso de manera consciente y crítica, propositiva y actuante. En síntesis, la institucionalidad educativa, respetuosa de la alteridad obrará de modo tal que logre gestar un verdadero educador capaz de tocar pedagógicamente al educando e introyectarlo en su propio yo. Un yo incluyente, que en virtud de relaciones pedagógicas de otredad, de enseñanzas que eduquen para el cuidado de sí mismo, del otro y de lo otro, permita concebir, a su vez, una nueva criatura con sentimiento y conducta ciudadana, lo que solo será posible si el educando advierte al educador como un cómplice, un amigo franco, comprensivo y leal que lo reconozca en su diversidad y acompañe hasta donde pueda en su proceso de aprendizaje y formación humana. Educar en la comprensión humana, en la formación de actitudes por y para la vida, impone un acogimiento situado $y$ visceral. El acogimiento pasa por reconocer hasta donde sea posible al estudiante en su diversidad única, a saber: sus conocimientos previos, intereses, sentimientos, contexto, ritmos y modos de aprender, generar ámbitos para acompañarlo en el afrontamiento de sus carencias y en el decurso, fortalecimiento y uso de potenciales necesarios para el desarrollo de "representaciones mentales integradas (Trites \& McGroarty, 2005)" y actuaciones que gravitan en la comprensión. Pero también es primario en el acto (léase, en el pacto) de acoger la empatía y la disposición a cargar con el educando comprendedor, entronizarlo en el yo del educador como condición para educar con arte en la enseñanza. Pues una enseñanza sin entronizamiento del educando, no educa, no aporta a la formación para una vida más humana. (Arboleda, 2020c) 
La gestación tendría lugar cuando el docente y la institución se disponen a ganar la conducta endógena, que se halla en la raíz del acto de educar, de abrirse al alumno, y el alumbramiento cuando éste logra proceder en las complejidades de la realidad de manera más consciente, crítica, comprensiva, emprendedora y constructiva, iniciando su experiencia ética como otro incluyente (Arboleda, 2019ª). Así, la enseñanza no se centraría en generar ambientes para la eclosión de aprendizajes sólidos; avanzaría además en la tarea inaplazable de formar seres moledores de certezas e información propagada, conscientes de su finitud, contingencia y vulnerabilidad, sensibles y responsables con el otro y con la vida planetaria, para lo cual se hace prioritario enseñar educando, proceder en este acto a la luz de la función de educar, y ésta a su vez desde el acogimiento como condición del PPF.

Finalmente y a fin de observar mejor la necesidad de apreciar los atributos de una CE en las prácticas educativas, como en los saberes epistemológico, didáctico y pedagógico, es oportuno capitalizar la reflexion epistemológica derivada de la teoría de la actividad en el marco de la caracterización de los sistemas de práctica matemática que llevan a cabo los individuos en condiciones institucionales específicas, adelantada por Arboleda, L. y otros (2014), con respaldo en Radford $(2009,2013)$ y Davidov (1988, p. 11), principalmente. La construccion de significados y sentidos que un sujeto realice en sus procesos de aprendizaje o apropiación (de "subjetivación del saber") para el logro de la comprensión ("consciencia individual"), no es una acción solipsista sino una actividad que, por serlo, constituye un proceso colectivo, interactivo e intencionado que se expresa en la relación del individuo como ser social hacia la realidad externa (mediatizado a su vez por el proceso mutante de esta realidad); es regulada por la inscripción de éste en un sistema de prácticas compartidas que configura un arsenal simbólico construido e institucionalizado por la comunidad en un campo de experiencias determinado, que permiten "objetivizar" su acción, orientándola hacia objetos específicos de su campo de actuación. Los grados crecientes o deficientes de comprensión (que no son del orden continuo ni lineal) se definen en el marco de los límites establecidos en la comunidad donde se inscribe el individuo.

De acuerdo con lo expresado, podemos decir que la CE (o desempeños caracterizados por un uso de conocimientos debidamente apropiados y con fines sensibles) no se halla aún instituida formalmente en los campos de saber, pues la actividad del comprendedor dirigida a realizar desempeños o usos entrañables de conceptos, saberes y conocimientos, no se advierte, como tampoco el acto responsable que derive en la pulsión de acoger a éste, en un hecho de insondable alteridad, en las prácticas de enseñanza, por lo que aquella y la causa ótrica requieren iniciar un camino de reflexiones y prácticas genuinas que al final aseguren o aplacen su legitimación/aceptación institucional. Para expresarlo con Ortega (2020), "si el otro, en su situación concreta de vida, no es el referente de la acción educativa, habrá entonces discurso, quizás brillante, pero no educación".

Arribar a un pensamiento didáctico y una comprensión de esta índole sería una forma de acercar las prácticas educativas y formativas a la raiz de la educación y al ser más hondo de los saberes asociados a esta, y de esa forma desvelar la vida que hay más allá del ripio o parodia de existencia que estas han venido reproduciendo a la luz de la episteme moderna dominante, globalizada. Ello no es posible sin la fabricación y uso de artefactos situados tempoespacialmente, dispositivos optimizadores (Agazzi, 2020), como la $C E$, que permitan a los profesores y todos los agentes educativos asumir con consciencia reflexivo edificadora la experiencia de mundo con sus conflictos, contradicciones, contingencias, incertidumbres y procesos que exacerba el modelo egocéntrico dominante, que en razón 
de la maximización del lucro agencia la minimización del ser humano y de la vida planetaria. Tal pensamiento representa, en conclusión, una oportunidad a flor de piel para que la didáctica queme sus pasivos de frialdad y encienda el fuego que abrase las prácticas de enseñanza que acompañarían los razonables propósitos de globalizar, si se prefiere glocalizar, no la sed de dinero, sino la humanidad misma en el decurso planetario, pluriversal.

\section{CONSIDERACIONES FINALES}

Urge una enseñanza que vaya más allá de la lógica de la institución y del sistema educativo, generada por ciertos intereses de poder; que apoye en la concepción de un estudiante que lea hermeneuticamente el aula, la sociedad y la realidad en su dinámica compleja, y sea protagonista de la construcción de una escuela abierta y soberana, que no se someta a la racionalidad antropocéntrica del mercado, y a su techné e hybris o irracional economía e idea de progreso ${ }^{75} \mathrm{a}$ expensas del equilibrio de los ecosistemas, que privilegia más una educación técnica (formar futuros trabajadores del establecimiento) que una educación instituida sobre lo humano (personas respetuosas de la otredad, artífices de mundos de vida, de impulso social y económico con espíritu de acogencia, solidaridad, fraternidad, valores íntimos de la existencia humana). Una enseñanza incondicional con el ser menesteroso, que cargue de sentido el devenir como potencialidad de todo ser para ser otro.

La PCE propugna por una formación a partir del reconocimiento de la función de educar y del valor primario de la educación, que acoja al educando en su singularidad, que le permita a éste construir

75 De acuerdo con Agazzi (2020), el progreso consiste, como mínimo, en no violar la moral en ejercicio de la ciencia y la tecnología, sino, posiblemente, en afinar la conciencia moral de cara al fomento de la vida misma". Idea diametralmente opuesta al sentido de progreso por el cual la duo-deidad somete inclusive a la educación y sus saberes, inversamente proporcional a la evolución de la vida (humana y planetaria), pues solo responde al libre desarrollo tecnocientífico - económico. Como sentencia este filsósofo, "no todo lo que es posible técnicamente es viable éticamente". y usar sus potenciales pluridimensionales para incidir en la construcción de escenarios de mayor dignidad para sí mismo, para el otro y lo otro que teje la existencia ${ }^{76}$. El reconocimiento y cultivo de las dimensiones que configuran la personalidad del sujeto es relevante en las apuestas formativas, tanto como la formación de pensamientos múltiples, no solo el pensamiento aislado (sea matemático, consciente, dialógico, divergente, creativo, ético, ecosistémico, lateral y sociocrítico), sino pensamientos múltiples actuantes y sobre todo generosos, los cuales movilizan y potencian valores, hábitos, actitudes y disposiciones.

Un asunto crucial de esta perspectiva es cómo llenar de contenido educativo, didáctico y pedagógico la pluridimensionalidad del sujeto educable para atenderlo en su alteridad; cómo proveer información pertinente y contextualizada (adaptada sensatamente al entorno social, ambiental, cultural, histórico y político), y cómo se ha de tratar y procesar ésta para que aquel la madure como conocimiento significativo en virtud de una comprensión consciente, crítica, ético estética y edificadora, no bastando conocer sino usando el saber con sentido de vida y comunidad. Sin ello la educación seguirá siendo un pamema, y los saberes que la rodean continuarán vistiendo el velo desde el cual la miran sin ver. Distantes de su centro de gravedad.

En esta senda la formación y los aprendizajes para la conservación de la vida no pueden tener como foco una didáctica entrópica, ensimismada y narcisa, sino emergente, radical, mesoaxiológica, ótrica, crítica y CE. Toda didáctica (el conjunto de indagaciones, conceptualizaciones, practicas, modelos, métodos, entre otras actividades que hacen parte del orbe del conocimien-

\footnotetext{
$76 \quad$ Aunque la PCE despunta a partir del primado inexorable de la educación, también reivindica las aspiraciones más sensibles, descontaminadas de egos e intereses personalistas, formuladas de acuerdo con las demandas más entrañables de las sociedades, y que aún aguardan, como aquellos, espacio en las agendas, políticas, sistemas y sobretodo realidades socioeducativas.
} 
to fundado sobre las enseñanzas y los aprendizajes) ha de ser sentida si se reconoce que este campo está ligado a la función de educar, de proteger la vida, sustancia de toda educación; la edificación, en los términos expuestos, sería un postulado fundamental para toda didáctica, y no está explícito en la praxis de este saber, ni tampoco en la práctica educativa ni en el discurso pedagógico. Si el proceso relacionado con la enseñanza tiene significado humano, debería dejar de ser potencia sin acto y emprender hacia la formación de mejores seres, acompañando de este principio la formalidad de influir en la construcción de aprendizajes, de aprehender la dinámica socio-cultural e histórica y la variación de los estados del saber, y en general de reconstruir las prácticas y saberes como actividades propias del hombre.

Dado el pasivo acumulado de la didáctica como saber y campo plural, que se ahonda con la velocidad de los cambios en los modos de relación, de vida y existencia que metamorfosean la actividad interna y externa del individuo (y que interrumpen la dinámica variacional e interconectada del universo ecosistémico que integra al mismo), ésta y por supuesto la educación, la pedagogía y demás saberes no tienen otra opción que rebelarse y reinventarse, entrar en una decidida insubordinación y desobediencia al régimen global, rentabilista y eficientista, para intentar debilitar el biopoder o poder con el cual gestiona la transgresión de los límites del saber y erosiona el mundo de la vida; de ese modo podrá regresar del exilio, destierro o letargo "eterno" de vaciamiento ótrico, de vínculos con el otro y lo otro, en razón de ocupar el territorio de sus ausencias edificadoras, y entregarse a la obra ética de humanizar, de formar ciudadanos planetarios que respeten el tejido y movimiento de interdependencias e interacciones propio del pluriverso, que aprendan a hacer de la existencia un arte, una techné tou biou, ganen consciencia comprensiva, sensible, ético-estética para vivir la vida humana y planetaria ${ }^{77}$.

\section{REFERENCIAS BIBLIOGRÁFICAS}

Agazzi, E., Rengifo, C. (2020). Filosofía, ciencia y verdad: el diálogo filosófico como método para la enseñanza y el aprendizaje de la filosofía. Rev. Guillermo de Ockham, 18(1), 9-18. doi: https://doi.org/10.21500/22563202.4769

Arboleda, J.C. ( 1995). Ser persona en el mundo de hoy. Ed. Lei.

Arboleda, J.C. ( 2.000). Mapas cognitivos: lectoescritura, aprendizaje y desarrollo del pensamiento, F. Penser- Unilibre.

Arboleda,, J. C. (2001). Toma de decisiones: pensamiento creativo, autonomía y emociones (Ed. - Penser).

Arboleda, J.C. ( 2.002). Mi proyecto de vida: desarrollo del pensamiento autónomo, cooperativo y emprendedor. Editorial Penser.

Arboleda, J.C. (2004). Relatorías y macrorrelatorías de investigación en el aula. F. PenserUAO.

Arboleda, J.C. (2005). Estrategias para la comprensión significativa. Editorial Magisterio, Bogotá.

Arboleda, J.C. (2007). Pensamiento lateral y aprendizajes. Ed Magisterio.

Arboleda, J.C. (2008a). Aprendizaje y comprensión: del enfoque de competencias al enfoque de comprensiones y proyectos de vida. Rev. Educación y Cultura, No 79.

Arboleda, J.C. (2008b). Aprendizaje por competencias, comprensiones y proyectos de vida personal y familiar, Editorial Penser.

Arboleda, J.C. (2011 a). La relatoría social "dis-

$77 \quad$ Este capitulo hace parte del libro: Arboleda, J. C. (2020). Enseñar educando, Editorial Redipe. 
positivo de investigación en el aula para fortalecer el pensamiento y el proyecto de vida social de los estudiantes, desde preescolar hasta universidad". Revista Educación y territorio. 1/1.

Arboleda, J.C. (2011 b). Competencias pedagógicas: conceptos y estrategias. Bogotá: Editorial Redipe.

Arboleda, J.C. (2011 c). Formación de pensamientos múltiples. Editorial Penser.

Arboleda, J. C. (2013). Hacia un nuevo concepto de pensamiento y comprensión. Revista Boletín Redipe (8/ 24).

Arboleda, J.C, Casanova, M. A. y Monereo, C (2014). Panel Proceso de evaluación en el Siglo $X X I$, UPN, Morelia, México. http://uniendoletrasnet.blogspot.com/2013/09/casanova-monereoy-arboleda-en-panel.html

Arboleda, J. C. (2015a). Formación para la vida: de las competencias a la comprensión edificadora, Revista Boletín Redipe. Vol. 4, №. 12, págs. $20-25$

Arboleda, J. C. (2015b). El currículo desde la pedagogía comprensivo-edificadora. Revista Boletín Redipe. Vol 22.

Arboleda, J. C. (2015d) La pedagogía de la alteridad en la perspectiva de la comprensión edificadora. Revista Educación y pensamiento. P 46.

Arboleda, J. C. (2017). Textos académicos. Editorial Redipe.

Arboleda, J. C. (2019a). La educación es inclusiva. Perspectiva comprensivo edificadora de la formación. (Texto de la conferencia impartida por el autor en el Ciclo: La tarea crítica de la educación incluiva. Celei, Chile.
Arboleda, J. C. (2019b). Educación y proyectos de vida. Revista Lope De Barrientos. Seminario De Cultura, Ucm, España, No. 11.

Arboleda, J. C. (2019c). Pasivos y desafíos en la educación. Revista Boletín Redipe: 8 (4).

Arboleda, J. C. (2020a). Presentación. En: "Función pedagógica, competencia técnica y transferencia de conocimiento. La perspectiva mesoaxiológica", Editorial Redipe Capítulo EE UU.

Arboleda, J. C. (2020b). Laudatio de Presentación de candidatura del Prof. Dr. D. José Manuel Touriñán López Al Premio Educa-Redipe (Modalidad Trayectoria Profesional). Convocatoria-2018.

Arboleda, J. C. (2020b). Educar para la evolución humana y de la vida. Revista Redipe, 9/6. 51-65.

Arboleda, L. (2011). Objetividad matemática, historia y educación matemática: https://www. researchgate.net/publication/280580703_Objetividad_matematica_historia_y_educacion_ matematica

Arboleda, L. y otros (2014). Filosofía, matemáticas y educación: una perspectiva histórico-cultural en educación matemática. Revista Científica, 3(20), pp. $72-90$

Arboleda, L. , Guacaneme, E., Torres, L. (2019). Estrategias curriculares de formación

en Historia de las Matemáticas en licenciaturas en Matemáticas en Colombia.

Revista Tecné, Episteme y Didaxis: ted, 46, 5780.

Arboleda, L.- Castrillón, G.(2007). Educación Matemática, Pedagogía y Didáctica. Revista Revemat, 2 N.1. Brasil.

Badiou, A (2016).: En busca de lo real perdido. Amorrortu, Argentina.

Behares, L. (2004). Enseñanza-aprendizaje revisitados. Un análisis de la "fantasía" didáctica. 
En: saber, sujeto y acontecimientos de enseñanza. Montevideo: Psicolibros/Waslala, p. 1130.

Behares, L. E (2013). Enseñar en cuerpo y alma: la teoría de la enseñanza y el saber en la pulsión. En: Dossiê: Cuerpo, Lenguaje y Enseñanza.

Behares, L. E (2016). La caracterización de la enseñanza como conjunto de técnicas para intervenir en los aprendizajes: un análisis crítico. Educação. Revista do Centro de Educação, vol. 41, núm. 3.

Bauman, Z. (2000). Modernidad líquida, Buenos Aires; Fondo de Cultura Económica.

Bourdieu, P. (2000 a). La dominación masculina. Barcelona: Anagrama.

Bordoli, E. La didáctica y lo didáctico. Del sujeto epistemológico al sujeto del deseo. In: Behares, L.; Corsaro, S. (Orgs.). Enseñanza del saber. saber de la enseñanza. Montevideo: FHCE, Universidad de la República, 2005. p. 17-25. [ Links ]

Ceballos E., E. - Puche N. Rebeca (2018). Funcionamientos Inferenciales en Niños Caminadores: un acercamiento al Microdesarrollo en una Tarea de Resolución de Problemas: Revista Colombiana de Psicología, Vol. 27, N. 2, págs. 117-135

De Bono, E. (1998). El pensamiento lateral, Paidos, Barcelona, 1998.

De Sousa Santos, Boaventura (2020). La cruel pedagogía del virus. Ciudad Autónoma de Buenos Aires : CLACSO.

Herrán Gascón, A. de la (2018). Fundamentos para una pedagogía del saber y del no saber. São Paulo: Edições Hipótese.
De la Herrán Gascón A de la (2018). Pedagogía del saber y del no saber. Revista Boletín Redipe. $7 / 3$.

De la Herrán Gascón A de la, Fortunato I. (2019) ¿Por qué desde la didáctica no se favorece la formación del profesorado?. Revista Boletín Redipe, 8/11.

Fairclough, N. (2008). El análisis crítico del discurso y la mercantilización del discurso público: Las universidades. Discurso \& Sociedad, Vol 2(1) 2008, 170-185

Didier Cariou, «DORIER Jean-Luc, LEUTENEGGER Francia \& SCHNEUWLY Bernard (dir.). Didactique en construction, construction des didactiques », Revue française de pédagogie [En ligne], 190 | janvier-févriermars 2015, mis en ligne le 31 mars 2015, consulté le 05 janvier 2020. URL :

http:// journals.openedition.org/rfp/4726

Dogliotti, P. (2012). Cuerpo y currículum: discursividades en torno a la formación de docentes de educación física en Uruguay (1874-1948). Recuperado de: http://posgrados.cse.edu.uy/ sites/posgradoscse.edu.uy/files/tesis_paola_ dogliotti.pdf

Escobar, A. (2012). Más allá del desarrollo: postdesarrollo y transiciones hacia el pluriverso. Revista de Antropología Social, 21, p. 23-62

Font, V (2003), Matemáticas y Cosas. Una Mirada desde la Educación Matemática. Boletín de la Asociación Matemática Venezolana, Vol. $\mathrm{X}$, No. 2.

Font, V (2006), Epistemología y didáctica de las matemáticas, Universidad de Barcelona:https:// irem.pucp.edu.pe/wpcontent/uploads/2011/10/ socializacion_1_font_ii_coloquio.pdf)

Foucault, (Foucault, 1967) "De los Espacios Otros". Conferencia impartida en el Cercle des études architecturals, 14 de marzo de 1967, publicada en Architecture, Mouvement, Continuité, 
n 5, octubre de 1984. Traducida por Pablo Blitstein y Tadeo Lima. Foucault, Michel. (1978). Las palabras y las cosas. Ed. Siglo XXI, Décima edición. México.

Foucault, M. (1983). La arqueología del saber. Ciudad de México: Siglo XXI.Gaete V., M (2015). Didáctica, temporalidad y formación docente. Revista Brasileira de Educação, v. 20 n. 62

Giroux, H (2020). Los maestros son una amenaza porque enseñan a hacer preguntas.https:// eldiariodelaeducacion.com/blog/2019/11/08/losmaestros-son-una-amenaza-porque-ensenana-hacer-preguntas/

Godino, J., Rivas, H., \& Arteaga, P. (2012). Inferencia de indicadores de idoneidad didáctica a partir de orientaciones curriculares. Praxis Educativa Brasil. 331-354.

González D., Mariano (2014). Continuidades y cambios en las disciplinas escolares: Apuntes para una teoría sobre la historia del currículum. https://www.researchgate.net/ publication/303024348_Continuidades_y_cambios_en_las_disciplinas_escolares_Apuntes_ para_una_teoria_sobre_la_historia_del_curriculum

Heclo, H. (2010). Pensar institucionalmente. Barcelona: Paidós.

Kant. (2003). ¿Qué es la Ilustración? en Filosofía de la Historia. Buenos Aires: Ed. Nova. Levinas, E. (1977). Totalidad e infinito. Ensayo sobre la exterioridad. Ediciones Sígueme S.A.U.

Runge P., Andrés Klaus (2013). Una introducción panorámica y comparada, Itinerario Educativo, Año xxvii , n. ${ }^{\circ} 62$ • Julio - Diciembre de 2013 • p. 201-240.

Ortega R.P.(2018). La escuela de todos. Revista Boletín Redipe: Año 7 Volumen 4.
Ortega R.P.(2020). Educar desde la experiencia del otro. Revista Boletín Redipe: Año 79 Volumen 2.

Nahuelquir y otros (2011). Analizando los 'no saberes': Reflexiones de procesos de memoriaolvido a partir de experiencias situadas de agenciamiento indígena. Revista Identidades, Argentina, $1 / 1$

Nussbaum, M., (2005ª). El cultivo de la humanidad, Barcelona: Ediciones Paidós Ibérica, 2005.

Ramírez, R. (2008). La pedagogía crítica. Una manera ética de generar procesos educativos. Folios (28): 108-119.

Riveros S., Hernán Javier (2020). El reto de educar en tiempos de la digitalización de la vida: hacia una pedagogía de las relaciones entre cuerpo, texto y tecnología. Revista Boletín Redipe.

Rodríguez, P (2017) Biotecnologías del yo. En: Costa, F. y Rodríguez, P. (eds) La salud inalcanzable. Biopolítica molecular y medicalización de la vida cotidiana. (pp. 91-113). Eudeba.

Rouse, M. (2009). Developing inclusive practice: $A$ role for teachers and teacher education. Education in the North, 16, 6- 13.

Serres, M. (2013). Pulgarcita. Fondo de cultura Económca, Argentina.

Touriñan, J. M. (2017). Reflexiones en torno a la función de educar. Revista Virtual Redipe: Año 6 Volumen 11

Touriñán, J. M. (2019a). Estudiar es actividad común externa y siempre educamos con la actividad. Una aproximación desde la perspectiva mesoaxiológica. Teoría de la educación. Revista interuniversitaria, 31 (2), 7-31. 
Touriñán, J. M. (2019b). Estudiar es actividad común externa y siempre educamos con la actividad. Una aproximación desde la perspectiva mesoaxiológica. Teoría de

la educación. Revista interuniversitaria, 31 (2), 7-31.

Touriñán, J. M. (2020 a). "Función pedagógica, competencia técnica y transferencia de conocimiento. La perspectiva mesoaxiológica", Editorial Redipe Capítulo EE UU.

Touriñán, J. M. (2020 b). Conocer, enseñar y educar tienen distinto significado, la diferencia permite hablar con sentido de enseñanza educativa.

Whitehead, Alfred (1957). "Los fines de la educación". Buenos Aires. Paidos.

Lipina, Sebastián J., Evers, Kathinka (2017). Neuroscience of Childhood Poverty: Evidence of Impacts and Mechanisms as Vehicles of Dialog With Ethics. Frontiers in Psychology 1-8. 